University of Rhode Island

DigitalCommons@URI

Open Access Master's Theses

1975

\title{
The Role of the Categories in Augustine's Formulation and Defense of the Trinity
}

James Davis Elkin

University of Rhode Island

Follow this and additional works at: https://digitalcommons.uri.edu/theses

\section{Recommended Citation}

Elkin, James Davis, "The Role of the Categories in Augustine's Formulation and Defense of the Trinity" (1975). Open Access Master's Theses. Paper 1762.

https://digitalcommons.uri.edu/theses/1762

This Thesis is brought to you for free and open access by DigitalCommons@URI. It has been accepted for inclusion in Open Access Master's Theses by an authorized administrator of DigitalCommons@URI. For more information, please contact digitalcommons-group@uri.edu. 


\section{THE ROLE OF THE CATEGORIES IN AUGUSTINE'S FORMULATION AND \\ DEFENSE OF THE TRINITY}

BY

JAMES DAVIS ELKIN

A Thesis Submitted in Partial Fulfillment

of the Requirements for the Degree of

Master of Arts

in

Philosophy

UNIVERSITY OF RHODE ISLAND

1975 


\section{AN ABSTRACT}

In De Trinitate Augustine of Hippo (354-430) gave his most complete analysis of the christian doctrine of the Trinity. The most crucial part of his logical analysis, Books V-VIII, shows Augustine attempting to handle the seeming logical dilemma of one God, yet Father, Son, and Holy Spirit. At the outset of his investigation, Augustine apparently had two concepts in mind. First, he accepted the Bible as authoritative; and obviously he accepted the idea that this authoritative Bible taught that God was one, and yet also three in some way. Also, Augustine worked from the contemporary understanding of Aristotle's categories in attempting his language analysis to decipher what could and should be said of the Godhead.

Augustine tried to remove terminological confusion which obscured the discussion of the Trinity in the late fourth century, and he also attempted to strip from the terms used of the Godhead the things which could not be said of God. Basically, he affirmed that God is one, yet three, and that God is immutable. In his estimation, for God to be God there could be no change in the Godhead. Three primary words were used to describe this Godhead: substance, person and relation. But, if these terms en- 
tailed the idea of mutability, they were inaccurate and could not apply to the Godhead. But language must be used if anything is to be conveyed about God. Therefore, because Augustine accepted the thesis, on Biblical authority, that God is one God, yet Father, Son and spirit, he had to strip from the terms that which entailed mutability. His result might be called spiritual substance, persons, and relations.

The view of reality projected by the Bible was, for Augustine, the true projection, and the scientifically demonstrable was not all of reality. He made no pretense of giving a proof of the Trinity; rather, he acknowledged the precedence of faith over knowledge, and tried to make more credible that which faith affirmed.

The real point of criticism, then, is one's frame of reference. Either there is a spiritual world, or there is not. If it exists, perhaps language must be adjusted to describe it. Certainly reality is not known independently of language; yet language may distort the view of reality by inaccurately protraying it. Augustine redefined his language to portray that which he accepted as reality. Words, for him, were functional, and not deterininative. Although human language can hardly describe the spiritual world wich is immutable, only by using this language with carefully guarded definitions 
can the spiritual world be discussed.

Therefore, if one expects De Trinitate to be a testable proof of the Trinity, it fails miserably. However, if one grants the possibility of a triune God, Augustine's work is most helpful in coming to a better understanding of the nature of that God. 
TITLE ABSTRACT

DE TRINI'TATE'S USE OF THE CATEGORIES 
TABLE OF CONTENTS

INTRODUCTION $\ldots \ldots \ldots \ldots \ldots \ldots \ldots \ldots \ldots \ldots \ldots \ldots \ldots \ldots$

Chapter

I. SOME ESSENTIALS IN UNDERSTANDING DE TRINITATE $\ldots \ldots \ldots \ldots \ldots \ldots \ldots \ldots \ldots$

The Milieu of Augustine's Day ........... 9

Augustine's Frame of Reference ......... 16

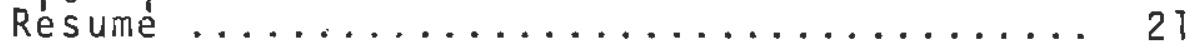

II. AUguSTINE'S ATTEMPT TO ESTABLISH THE UNITY OF GOD ................. 22

The Augustinian Method ............. 22

God as Substance ................. 24

The Nature of the Godhead ........... 35

Implications .................. 42

A Short Evaluation ............... 52

III. AUGUSTINE'S REFUTATION OF "SINGLENESS"

IN THE GODHEAD ................. 55

The Problem ....................... 55

The Terminology of the Trinality ........ 60

Implications .......................... 79

A.Short Evaruation .............. 84

CONCLUSiON $\ldots \ldots \ldots \ldots \ldots \ldots \ldots \ldots \ldots \ldots \ldots \ldots \ldots \ldots$

SELECTED BIBLIOGRAPHY $\ldots \ldots \ldots \ldots \ldots \ldots \ldots \ldots .95$ 


\section{INTRODUCT ION}

No other doctrine is so fundamental to the understanding of the Christian faith, and yet so elusive of precise interpretation, as that of the Trinity. Augustine of Hippo (354-430) well knew the intrinsic problems with such a task as giving an accurate depiction of the doctrine, as he states near the beginning of his work De Trinitate: "I am compelled to pick my way through a hard and obscure subject" (I.3.6.) 1 ; and "in no other subject is error more dangerous, or inquiry more laborious, or discovery of truth more profitable." (1.2.5.)

\section{The Early Church}

From the first days of the Christian church, the problem of understanding the doctrine of the Trinity was a matter of practical interest. Early investigations of the doctrine were guided by such extraordinary confessional declarations as the "baptismal formula." 2 The early

lunless otherwise noted, bracketed references refer to the Book, Chapter, and section of the main text of the study: Phii ip Schaff, gen. ed., A Select Library of the Micene and Post-Nicene Fathers of the Christian Church, vol. 3: on the Trinity, by st. Augustin, trans. Arthur West Haddon, revised with an introductory essay by William G. $T$. Shedd (Buffalo: The Christian Literature Company, 1887 ).

2Matthew 28:19--"in the name of the Father, and of the Son, and of the Hoiy Spirit." 
Christians believed in God, and they believed in God with the distinctions of Father, Son, and Spirit. These early Christians prayed to Cinrist, believed $H i m$ to be the Son of God and God Himself, and expected His return to judge the world. The natural consequence of this belief was for them to examine carefully the relationship of this son to the Father, while all the time working from the basis of the fundamental principle of their heritage, monotheism. Likewise, when they wrestled with the way to understand the nature of the Godhead and of the Son's relation to the Father, they soon turned to the relation of the Spirit to the Father and the son. Thus, in these examinations, the church was faced with the intricate dilemma of how to understand the concept of Father, son, and Spirit, yet one God. They had to consider how an immaterial being such as God could be conceived as three; and then, when the threeness had been established, they yet had to justify some way of considering these as one. In the second century, Athenagoras expressed this concern by saying that Christians "know GoJ and His Logos.. "Iand 7 what is the spirit," and he added that they also "know what is the unity of these three, the Spirit, the son, and the Father, ard their distinction in unicy." 3 They accepted the

${ }^{3}$ Harry Austryn wolfson, The Finilosopiny of the Church Fathers, 3d ed. Cambridge: Harvard University Press, $19 \overline{01}: 0.308$. 
idea of the three in the one God. However, in coming to grips with now they might credibly explain one God in three, the early church wrestled long, and, at times, bitterly.

\section{Augustine of Hippo}

Augustine's life and intellectual background well equipped him for the struggle with the doctrine of the Trinity. Augustine, who was the son of a pagan father and a Christian mother, received the education of a rhetorician. Because he was not easily satisfied with naive solutions to the ultimate questions of life and reality, he explored for himself the philosophies of his day. Augustine embraced and subsequently rejected Manicheanism, skepticism, and aspects of Neo-Platonism until he had, as he describes in his Confessions, a conversion to Christianity. From that time, he expended his eminent abilities as philosopher and theologian examining, explaining, and propagating his newiyfound Christian phijosophy.

In De Dactrina Christiana, Augustine explains that all intellectual pursuits must serve to assist the Christian in understaniing the faith of the scriptures. With his conversion had come a change in his attitude and purpose. For the converted Augustine, phirosophy assumed a subservient role, a role of nourishing and deepening the understanding of the Christian faith. No jonger could philasophy be pursued as a study for its own sake. How likely it was that Auglistine would soon turn his abilities 
and interest to examining and attempting to explain the perplexing doctrine of the Trinity.

\section{De Trinitate}

Augustine produced several shorter discussions of the Trinitariandoctrine. References are found in: Contra sermonem Arianorum; Collatio cum Maximino; Contra Maximinum haereticum; Letters $\underline{X I}$ and $\underline{C X X ;}$ and De civitate Dei XI, 10. However, it is in De Trinitate that Augustine gives his most complete and mature explanation of his notion of the Trinitarian doctrine. Augustine has been venerated both as a philosopher and a theologian, by the medieval and the modern church, by the Roman and Protestant churches; one of the major reasons for the high esteem of Augustine has been the influence of his closely reasoned treatment in De Trinitate. As one critic has said of his contribution:

Augustine's treatise on the Trinity ranks as one of his foremost works, and indeed as one of the ablest presentations of the doctrine in Christian literature. Few have wrestled with its discouraging problesns or penetrated its mysteries so successfully as Augustine. He brought to the task a keen philosophic mind and a theological grasp which have seldom been rivaled. 4

Whether justifiably or not, Augustine's De Trinitate has been recognized as a high-water mark in the history of

4Cyrii C. Richardson, "The Enigma of the Trinity," in A Companion to the Study of St. Augustine, ed. Roy W. Bat Eenhouse (New York: Oxford University Press, l969), p. 235 . 
interpreting the doctrine of the Trinity, as the previous quotation would indicate.

Early in De Trinitate Augustine explajns that his purpose therein is to demonstrate that the Trinity "is the one and only and true God, and also how the Father, the son, and the Holy Spirit are rightly said, believed, /and $\bar{T}$ understood, to be of one and the same substance or essence." (I.2.4.) The problem faced by Augustine was that of the inter-relations of three in one, and one in three. In De Trinitate, Augustine applies himself to the ontological distinctions, to those distinctions dealing with the actual Being of God, rather than those distinctions expressing God's association with creation. Not God creating, redeeming, and sanctifying His people, but God Himself as distinct from creation serves as Augustine's subject of analysis. How can one understand the Being of God, as three in one and one in three? In dealing with such a question, De Trinitate divides into two main sections: (1) the exegetical section, Books I-VII, in which Augustine deduces the doctrine of the Trinity from the Scriptures by examining the passages, and comparing, contrasting, and refuting objections; and (2) the speculative, Books VII-XV, in which he attempts to ilusstrate the Trinity by analogies found in nature and in the human mind. Our interest lies primarily with a portion of the exegetical part, particulariy Books V-VII. 


\section{A Continuing Skepticism}

Although Augustine's formulation of the doctrine of the Trinity yet remains the one accepted by the majority of Protestant and Roman church bodies today, it must be admitted that his solution to the Trinitarian question has not gone uncontested through the years. Many scholars, both theologians. and philosophers, continue to object to, refute, and disparage the one in three and three in one of De Irinitate. Adolph Harnack, the noted theologian, is one prime example of the objectors. His major criticism seems to be that, although Augustine credibly establishes the unity of the Godhead, in the process he actuaily destroys the possibility of true multiplicity within the Godhead. Harnack says:

We can see that Augustine only gets beyond Modalism by the mere assertion that ha does not wish to be a Modalist, and by the aid of ingenious distinctions between different ideas. . . for Augustine employed the whole resources of his philosophy in the endeavour to overcome the coptradiction which could not be overcome.

In another place Harnack calls these distinctions made by Augustine in De Trinitate "sacred paradoxes." 6

Another critic, L. L. Paine, says: "How so logical

a thinker could have thus lost himself in the mazes of

5 Adolph Harnack, History of Dogme, 7 vols. (London: Williams and Norgate, ?894 , 4:137, rote.

6 Ibid., p. 135. 
monism and played jumping-jack with his own logic would be a profound mystery to any one who had not studied the history of human speculation."7 Perhaps with tongue-incheek, Paine implies that he understands Augustine's foolishness because he can see that the history of thought multiplies examples of such wrong thinking. Augustine is mistaken, and grossiy so, according to Paine; but such mistake is natural to man, and is quite understandable.

Are Harnack and Paine correct in their evaluation?

Does Augustine fail in his purpose? Has history given great esteem to this philosopher and his De Trinitate unduly?

This kind of question forms the crucible for our study of Augustine's statement of the doctrine of the ontological Trinity.

\section{A Projection}

In this study of De Trinitate, there will be three main sections and a concluding statement. The first section will give a more complete and detailed understanding of the problem of the doctrine of the Trinity in the historical milieu, and of Augustine's frame of reference which colored his analysis of the doctrine. The second section will deal with Augustine's attempt to establish the unity of the Godhead. In the third section, the very complex problem of

7Levi Leonard Paine, Critical History of the Evolution of Trinitarianism (Boston: Houghton, Miffín, and 
the denial of singleness in the Godhead will be examined. In this final section, Harnack's criticjsm will either dethrone De Trinitate, or crumble itself. Then, we shall make some concluding observations concerning Augustine's analysis. 
SOME ESSENTIALS IN UNDERSTANDING DE TRINITATE

\section{The Milieu of Augustine's Day}

Augustine's formulation of the doctrine of the Trinity came only after many years of long and laborious analysis and interpretation of the Scriptures by other churchmen. Often, however, this work was mixed with the philosophical bias of or simple misunderstanding on the part of the particular church father. A brief account of some of the previous labor will no doubt give an indication of the strength or weakness of De Trinitate, as well as an indication of the turmoil in which the early church found herself in trying to give a clear statement to the perplexing notion of one in three.

The possibility of three subsistences in one Godhead was occasion for much controversy in the early church. As the church attempted its resolution of the concept, two tests became a "Rule of Faith" in the matter; the baptismal formula of Matthew 28 and the true Deity of Christ established the boundaries for discussion. ${ }^{1}$ No analysis

'Benjamin Breckinridge Warfield, "Trinity," International Standard Bible Encyclopedia, 5 vols. (Grand Rapids: Wm. B. Eerdmans PubTishing Company, 1939), 5:3022. 
could renounce or neglect either of these two concepts; they established the controls for all examination. The three Persons of the baptismal text, and the true Deity of the Son were fundamentals to the Christian faith.

However, extremes in interpretation appeared quite quickly, and the emphasis of the extreme led to unsatisfactory solutions,

\section{Subordinationism}

In the second century, the prevailing thought of Philo and the Middle Platonists held powerful sway over the developing Christian church. As a result, the way in which the Son was understood to be true Deity suffered compromise at the hands of some. This platonized form of Christianity associated the Son with the pagan Logos, which, as a result, placed Him in a halfway position between God and man. This overemphasis is understandable; in the attempt to give a credible explanation of the plurality expressed in the Rule of Faith, the unity of the Godhead suffered misstatement, and became incomprehensible. The Son became a kind of "second class" form of God, and subordination resulted.

Perhaps an historicai example of this kind of overemphasis is appropriate. In the second century Logos controversy, Justin Martyr described the Son as the firstborn of creation, and the "entire Logos." Although he 
thought of the Son as existing before creation as a power and a person, he said that He was generated by the Father with a view to, and for the sake of, creation. As one fire kindles another, the Son was generated by the Father. The result was a subordination of the Son to the Father, in the essence of the Deity, and not just in the economy. ${ }^{2}$

A similar, though more thorough, perversion occurred in the fourth century. Arianism proclaimed that God is unbegotten and without beginning. But $\mathrm{He}$ is not the Father from eternity, by His very nature; He is only Father as a result of creation. Prior to the creation of the world, God brought into existence a kind of "intermediate being to act as a medium through whom he created all things, a distinct 'hypostasis', or 'essence', called in Scripture wisdom, son, logos, image of God, etc.; and He also called into existence a third and lower hypostasis, namely, the Holy spirit." 3 As a kind of lower form of God, the son supposediy was created, produced, or generated by God out of nothing, and endued with the closest approximation of the perfections of God Himself. Thus, the Son was, as

2 Herman Bavinck, The Doctrine of God, trans. William Hendriksen (Grand Rapids: Wm. B. Eerdmans Publishing Company, 1951), p. 276.

${ }^{3}$ Ibid., p. 288 . 
Robert L. Dabney has said, a "deputized divinity," used by God as His agent in all His works of creation and redemption. 4

"Subordinationism" fits both of these examples because, in both, the son is no more than a lower form of the Divine essence; He has not been, both would say, from eternity of the same essence of God. Only at the point of creation is there a need to distinguish the Son from the Father. At the very best, the son is in only a subordinate relationship to the Father.

The early church wrestled with this problem of subordinationism. With an overemphasis of the three, the true unity of the Godhead is destroyed; but the unity inust be affirmed. Eventually the concept of essential subordination was branded heresy by the Council of Nicea in the fourth century.

\section{Monarchianism.}

Another error of the early days of the church tayght that the Father, Son, and Holy Spirit were so completely identified, that God only revealed Himself at different times in the form of one of the three. The three Persons were thought of as only different expressions in the life of God. At one time, God appeared as Father, then as Sor, and yet agaila as Hoiy Spirit. A variation of monarchianism

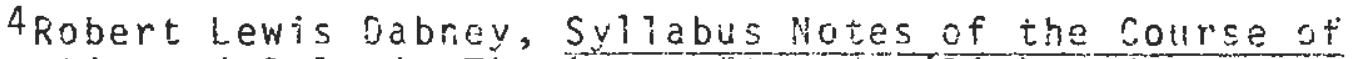
Systematic and Polent: Theology, $5 \mathrm{tn}$ ed TRtchmond: Presbitarian commetee of putication, i371), p. 175. 
taught that these appearances were only "modes" of the existence of God, and hence resulted the name "Modalism."

Sabellius was the most prominent of the modalists. He taught that Father, Son, and Spirit were merely three names for one and the same God. There could not be a trinity of essence in the Godhead, but merely one of revelation; there could be no real distinctions in the Divine Being, but the Divine unity could only revea? Himself successively in three modes or forms. The relations expressed by the three different names are coordinate, and as a unity they describe the one God expressing Himself diversely. These differences were used by God to meet the different needs of the occasion; therefore, there was no permanence about the modes of expression. The consequence of this modalism entailed no real incarnation of God, no personal and indissoluble union of the Godhead with the manhood in the incarnation. When the functional roles were completed, each of the functional titles ceased to be significant.

Thus, the Father, Son, and Spirit could only be one and the same Being, but each could only be an expression of different functions of God as He is known through and by creation. There could be no such thing as ontological distinctions in the Godhead; only when God manifested Himself to and through creation could economic distinctions exist. The God of sabellius was, therefore, a monad, a single God appearing in three different forms. God 
assumed these three different forms, according to Sabellius, by a process of expansion and contraction. At the end of the process, the Trinity ceased to exist in any form.

This Sabellian form of monarchianism is particularly important to us, because it is this "modalism" of which Augustine is accused by Harnack. ${ }^{5}$ Certainly, this is a pitfall which Augustine had to avoid if he hoped to give a credible explanation of the Trinity.

Nicea

When the Nicene Council met to consider the eternal Sonship and ópoovocov, it rejected subordinationism by saying that the son is "homoousios toi patri." Although Sabellianism, as such, was not an issue, the council rejected forms of monarchianism by implying that the Persons were Persons in the Being of God, and were not merely economical manifestations with respect to the work of God in the world. Nothing less was at stake at Nicea than the rejection of polytheistic mythology in the form of Arianism, on the one hand, and the retention of the Deity of Christ on the other. Nicea attempted to choose the correct path to maintain the Deity of Christ and reject Arianism."

$$
5 \text { Harnack, } 4: 131 \text {, note. }
$$


The Cappadocians

Although Nicea was a triumph over improper perceptions of the nature of God, distortion continued in many areas. The Council of Constantinople (381) demanded and received widescale acceptance of what Nicea had determined. This success at Constantinople was made possible by the prominence of three theologians called the "Cappadocians."

As had been done traditionally, the Cappadocians began their investigations of the doctrine of the Trinity from the standpoint of the plurality within the Godhead. Three "hypostases" or "forms of being" were one God. They considered these three to differ primarily in terms of derivation. They used the now well-known analogy in an attempt to depict the Trinity: the Trinity is Iike three men, Peter, James, and John. These are three individuals who have something in common, manhood. Because they have manhood as a common factor, this trinity could be properiy described as "three man." The Cappadocians were quick to acknowledge, however, the limitations of the analogy; in their opinion, the only actual distinctions inhererit in the Trinity were those of derivation. This meant that the Father was underived, the son was of the Father, and the spirit proceeded from the Father and son. As Cyril

Richardson has observed:

Thus, the 'hypostases' are not particuiar instances of a 'uriversal', the divine 'ousia'; that would imply tritheism. The cappadocian idea is more subtle. The 
nature of the Godhead more nearly corresponds in their thought to Aristotle's idea of a particular concrete existence (prote ousia), not to the 'deutera ousia' which members of a species have in common. 6

Obviously, the Cappadocians were attempting to make a careful distinction between "ousia" and "hypostasis." The ousia in the Godhead is identical in each Person. However, the analogy of manhood breaks down, because it is simply a generic term and fails because it exhibits the qualities of the Aristotelian "deutera ousia."

Nevertheless, the Cappadocians established the use of the Greek words, "ousia" and "hypostasis," in distinguishing the nature of the Trinity. However, the obvious affinities with Sabellianism continued to produce misunderstandings. We shall return to the terminological developments, but for now it is important to note that the Greek statement of the nature of the Trinity prior to Augustine's effort conceived of God as three hypostases and one ousia.

\section{Augustine's Frame of Reference}

Norie can deny that everyone has a frame of reference, including basic presuppositions, which significantly affect one's basic outlook. Two aspects of Augustine's frame of reference are extremely important in the understanding of De Trinitate.

$$
\text { 6richarison, "Enigma," p. } 237 .
$$


Christian Faith and the Authority of the Scriptures

The primary assumption in all of Augustine's work subsequent to his conversion is that faith must be prior to true knowledge; one must "believe in order to know," or "praecedit fides, sequitur intellectus." For Augustine religious faith preceded knowledge and was the key to that knowledge. As a natural consequence, he could begin his investigation of the Trinity only on the acceptance of certain presuppositions a priori. These are propositions accepted as true only on the testimony of the Bible. Such reliance on the Scriptures is a trait Augustine held in common with those for whom he wrote De Trinitate; he attempts to arrive at a deeper intellectual understanding of the accepted facts concerning the Trinity. The data given by the Scriptures include the unity of God; His manifestations as Father, Son, and Holy Spirit; and the equal Deity of all three persons. This much had been accepted by the church; Augustine faced the task of deciphering how the church could inteligibly think of the God who has thus revealed Himself. 7

Perhaps one might say that Augustine thought it enough to demonstrate the rationality of the Trinitarian doctrine to those who already believed the doctrine. That such seems to have been the case is indicated by Augustine himself:

${ }^{7}$ Leonard Hodgson, The Doctrine of the Trinity, $7 \mathrm{th}$ ed. (Londan: James Nisbet and Co., 1964), pp. T47-148. 
Beginning, as I now do henceforward, to speak of subjects which cannot al together be spoken as they are thought, either by any man, or, at any rate, not by myself; although even our very thought, when we think of God the Trinity, falls (as we feel) very far short of $\mathrm{Him}$ of whom we think, nor comprehends Him as He is; but He is seen, as it is written, even by those who are so great as the Apostle Paul 'through a glass and in an enigma'." (V.1.1.)

In concluding Book VII, Augustine says: "And if this cannot be grasped by the understanding, let it be held by faith, until He shall dawn in the heart who says by the prophet, 'If ye will not believe, surely ye shall not understand'." It is from this foundation of faith that Augustine draws upon all his abilities to gain some understanding of the interrelationship of the individuals of the Trinity. All of the sciences had to be subordinated to the service of nourishing and deepening the faith; they had to function for the sake of elucidating the christian philosophy, to enable those who believed to come to a better understanding of the faith as it is presented in the Word of God.

Therefore, one must admit that Augustine's treatise makes no pretence of being a unique argument to establish the truth of the doctrine of the Trinity, so much as it is an elucidation of that doctrine. Apparently Augustine's intent in the De Trinitate is to explain as rationally as possible the teaching of the Scriptures concerning the Trinity. This a priori faith principle is essential to the 
understanding of what Augustine does in De Trinitate. Faith precedes knowledge, and the scriptures are true. Therefore, Augustine must accept what the Bible teaches and explain it as clearly as possible.

\section{Aristotle's Categories}

The Aristotelian categories play a significant role in Augustine's treatment of the Trinitarian doctrine. By employing the categories to his own advantage, Augustine attempts in Books V-VII to gain some light upon the distinction between substance and accident, and upon the general problem of predicamentals; by using the categories he classifies the things that can be said of God.

What are the categories? The ordinary meaning of

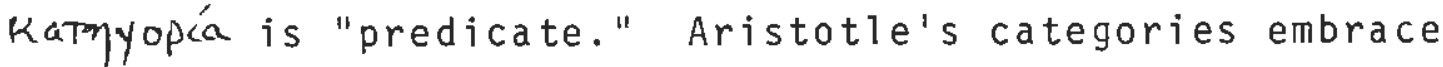
the major types of concepts governing or defining all of scientific knowledge. The categories are: reality or substance, quantity, quality, relation, place, time, position, possession, activity, and passivity. 8 . The first of the categories, substance, has among its members individual substances. ${ }^{9}$ The rest of the categories are a list of the "widest predicates which are predicable

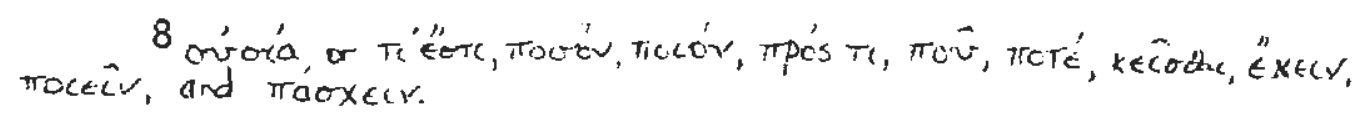

9 secondary substances are also substances, but not ingividuals. See p. 27. 
essentially of the various nameable entities, i.e., which tell us what kinds of entity at botion they are."10 One use of the concept of category is to aid language analysis. Of course, these language distinctions have to be more than just mere mental representations; they must refer to, represent, or embody something, or they are void of meaning. It is by using this scheme to help in language analysis that Augustine attempts to give a credible explanation of the Trinity. By using the philosophical analysis available through the use of the categories, Augustine attempts to get beyond the often misleading forms of language used by others to explain the nature of the Trinity. Therefore, the categories enable language distinctions to describe metaphysical distinctions in De Irinitate.

That Augustine found the categories extremely important in his study of the Trinity is quite obvious. Near the beginning of Book $V$ Augustine says that God is - . good without quality, great without quantity, a creator though He lacks nothing, ruling but from no position, sustaining all things without 'having' them, in His wholeness everywhere, yet without place, eterna? without time, making things that are chargeable, without change of Himseif, and without passion. (V.1.?.)

Curiously, Auglastine eliminates two of the categories from this list, substance and relation; then he denies the

10W. D. Ross. Aristot?e (London: Methuen \& Co., LTD, $1905), p, 23$. 
propriety of using these terms such as quality and quantity of the nature of God. He will deal extensively with substance and relation, but initialiy he denies that the other logical descriptions can be made of God.

\section{$\underline{\text { Résumé }}$}

In the fourth century, the church attempted to articulate its belief concerning the Trinity. Basically, in its councils the church established the guards for the Trinitarian doctrine. God is one; the son and the Spirit as well as the Father are one God. Subordination and monarchianism were rejected as improper modes of explaining the way the church must understand the Trinity. Just prior to Augustine's treatise, the Cappadocians carefully distinguished between hypostasis and ousia, but they did not explain to the church how three hypostases could be one ousia. From his assumption of the faith principle and the absolute authority of the Bible, and by the aid of the categories of Aristotle, Augustine wrestled to unravel the linguistic and logical maze of the Trinity. 


\section{AUGUSTINE'S ATTEMPT \\ TO ESTABLISH THE UNITY OF GOD}

The Augustinian Method

In the opening pages of De Trinitate, Augustine assumes what seems to be the traditional mode of beginning the analysis of the Trinitarian doctrine. He says that the study of the doctrine is an examination into the manner in which the "Trinity is the one and only and true God, and also how the Father, the Son, and the Holy Spirit are rightly said, believed, $L \bar{a}$ d $\underline{T}$ understood to be of one and the same substance, or essence." (1.2.4.) The usual manner of the early church fathers, as in the case of the Cappadocians, had been to proceed from the multiplicity of the Trinity to the unity. The question of the unity of the Godhead came subsequent to the analysis of the three; the earlier problem had been to guarartee the Deity ố Jesus and the Spirit as well as that of tre Father. Particularly among the Ereek fathers of the early church, the unity of the Godhead received consideration only after the Son received ful] recognition as true God with the Father. Augustine seems to approach the Trinitarian discussion from the same traditional metrod. But exactly the opposite 
is actually true in De Trinitate. For Augustine, the problem is to consider the nature or unity of God before considering the trinity of Father, Son, and Spirit. In the earlier days, the "One God" was identified as the Person of the Father; from this point the church examined the principles of generation of the Son and procession of the Spirit. 1

But Augustine does not think of God as the Father; by beginning with "God" he begins with the simple Divine nature or essence.

At the beginning of Book VII, Augustine writes: there is "one God, one good, and one omnipotent, the Trinity itself." In De Civitate Dei Augustine says similarly that "one God is this Trinity." (11.10). Again in De Trinitate, he explains that "the Trinity is the one and only and true God . . LandT are one and the same substance or essence," (I.2.4.); and "the Father, arid the Son, and the Holy Spirit constitute a divine unity of one and the same substance in an indivisible equality." (I.4.7.)

Augustine starts from the assumption, then, that there is but one eternal substance in the universe. This one substance, or essence, is God. God, as Being, is essentially one. He is "una res," "summa simolex essentia." He affirms

1W. S. Bishop, The Development of the Trinitarian Doctrine in the Nicene and Athanasian Creeds, A Study in Co., 1910), p. 39 . 
that there exists a numerical unity of essence, and not simply a generic unity. As God is Father, Son and Spirit, the unity of essence is set squarely in the forefront. ${ }^{2}$

\section{God as Substance}

Augustine affirms that God is the only unchangeable substance by saying that "He is however, without doubt, a substance, or, if it be better so to call it, an essence, which the Greeks call ousia." $(V .2 .3 .)^{3}$ As a result, "we do not say three essences, so we do not say three greatnesses, but one essence and one greatness. I say essence, which in Greek is called ousia, and which we call more usually substance." (V.8.9. $)^{4}$ Again, he says that "most of ourselves who treat these things in the Greek language, are accustomed to say, píar ovióor, tpeés vitrootáoecs, or in Latin, unam essentiam, tres substantias." (V.8.10.)

Augustine considers first the Godhead, but what is the nature of that Godhead? Much of Book $V$ deals with this very question. The terms involved, such as substance and essence, and the concept of a being or reality which could

2"Unus quippe Deus ipsa Trinitas, et sic unus Deus quomodo unus creator"--Contra sermonem Arjan., 3 .

3 "Est tamen sine dubitatione substantia, vel, si melius hoc appellatur, essentia, quarn Graeci ousian vocant."

4 iipropterea sicut non dicimus tres essentias, sic non dicimus tres majnitudines, sed unam essentiam et uriam magnitudinem. Essentiam dico, quae ousia graece dicitur, quam usitatius substaritiam vocamus." 
be attributed to the Godhead, come from the realm of philosophy. The Greek church used the term ousia in the sense of real existence or actual being, according to Augustine. Although Plato and the early philosophers had discussed the concept of being, Aristotle fixed for the later generations the actual connotation of the word ousia. 5

$$
\text { Aristotle's "ousia" }
$$

Aristotle used ousia in Metaphysics Delta 8,1017 bloff a s: 6

5j. F. Bethune-Baker, An Introduction to the Early History of Christian Doctrine, 9 th ed. CLondon: Methuen and Co., 195 T), p. 237.

$60 f$ Substance, Aristotle says in the Categories:

4a10: "The most distinctive mark of substance appears to be that, while remaining numerically one and the same, it is capable of admitting contrary qualities."

4a19: "The same individual person is at one time white, at another black, at one time warm, at another cold, at one time good, at another bad."

4a30: "It is by themselves changing that substances admit contrary qualities. It is thus that that which was hot becomes cold, for it has entered into a different state."

4b17: "To sum up, it is a distinctive mark of substance, that while remaining numerically one and the same, it is capable of admitting contrary qualities, the modification taking place through a change in the substance itself."

Michael Durrant summarizes the various usages of ousia by Aristotle in Theology and Intelligibility (London: Routledge \& Kegan PauT, (973), p. 88, as:

(1a) something not sajd of a subject in the sense of a "simple" body.

(1b) something not said of a sutject in the sense of an individuai, sych-and-such.

(2) $T^{\circ} \mathrm{c}^{\prime}, \hat{\mathrm{Y}}$ eirac

(3) $r s i c r c$ (second substance)

(4) mat.ter.

(5) form (Eids).

(6) formal explanation (céteor). 
(1) the simple bodies: earth, air, fire, water, etc. These are called substances because they are not Ka $\theta^{\prime}$ víto-

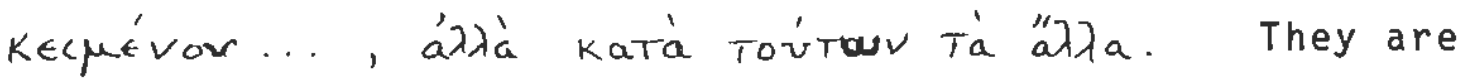
not things said of a subject, but other things are said of them .

(2) that not said of a subject, but which is the explanation (acic) of a thing being what it is. An example would be the soul of an animal.

(3) that not said of a subject, but which determines and indicates the individuality of the subject, and the destruction of which brings about the destruction of the subject.

(4) a set of qualities which something else has in order for that something to remain the same something throughout a time period. This might be thought of as the essence of the thing.

Against the backdrop of Aristotle's definition of substance must be viewed all subsequent discussion of being, substance or essence. A substance for Aristotle was that which persists through superficial change, and that which is qualified by predicates and cannot become a predicate of something else. A substance has qualities, and undergoes change in respect to the increase or decrease of its particular qualities. It is par excellence the subject of predication. A substance cannot exist without the predicables; it is a unity involving not only qualities but also an unknown element called matter or substance; but substance 
cannot exist in the abstract without the other categories of predication. 7 For Aristotle the real and intelligible re-mained one.

Although true substance for Aristotle was individual substance, he did allow for what he called secondary substance. In abstracting that which is essential to the individual, generalizations can be made concerning those qualities. The individual is true substance, but once removed is the secondary substance of species. Such universals as species and genus do not exist apart, but only as they are found in the individuals. Substance, as the first of the categories, entails other categories. Therefore, it entails mutability. In the Categories Aristotle actually indicated that substance is characterized above all by its power to be the recipient of qualifications. (4al0) It is this understanding of substance which Augustine builds

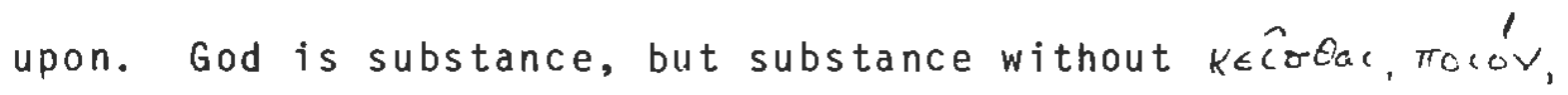

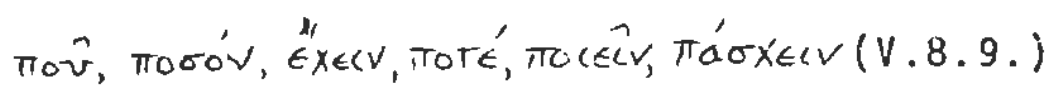

\section{Hypostasis}

For Augustine ousia clearly means substance, but confusion results with another word which was being used, hypostasis. Although the Greeks made a distinction with the

7Professor Ross says in Aristotle, p. 165: "A qualityless substance is as impossible as a quality which does not presuppose substance. The substance is the whole thing, including the qualities, relations, etc., which form its essence, and this can exist apart. It implies qualities 
word, Augustine finds it without clear distinction. Aristotle had used this word only in its 1 iteral meaning of "a standing beneath" or "that which stands beneath." It could have referred to that which remains as a result of the action of subsisting, or the action itself. 8 Previously the word ousia had been commonly used as the underlying existence of any given thing, and hypostasis would often serve as its equivalent. Because it was thought to express the vehicle of all qualities, hypostasis was still thought to be equivalent to ousia at the time of Nicea. 9 BethuneBaker attempts to substantiate the argument that the words were used synonymously at Nicea by quoting Athanasius' de Decr 20. There Athanasius repeats the Nicene anathema, with only $\dot{E}\}$ étépas crícías as the guarding phrase. In one of his latest writings, Ad Afros 4, he refuted the objections

but these are not something outside it which it needs in addition to itself. A quality, on the other hand, is an abstraction which can exist only in a substance. Obviously, if this is his meaning, Aristotle is thinking of substance as the individual thirg. Secondary subtances (i.e., genera and species), being universals, cannot according to his own doctrine exist apart, but must be supplemented by the special qualities of their individual members."

${ }^{8}$ Bethune-Baker, Introduction, p. 237.

9However, Bul?, for one, thought the terms had been separated by the time of Niceaa, and that the Council actuaily anathametized two neresies by using the two terms in a parallel fashion. So according to willian G. T. Shedd, Dogmatic Theology, 2 vols., $3 \mathrm{~d}$ ed. (New York: Charles Scribner's sons, 1891), 1:270. 
brought against the words as being non-scriptural by saying, "hypostasis is ousia and means nothing else but simply being."10 The least that can be said is that Athanasius, one of the primary figures of the Nicene days, considered there to be no distinction between the two terms. However, certainly this is not the case with some of the Greeks, especially the Cappadocians.

Only at Alexandria (362) were distinctions introduced to allow the separation of ousia and hypostasis. From this time the church began to speak of "treis hypostaseis." Although confusion continued, the Greek fathers became more accustomed to use ousia to express the existence or essence or substantial entity of the Godhead, and hypostasis to express the existence of the particularity of the Father, Son, and Spirit.

Basil of Caesarea, one of the Cappadocians, explained the newly-found distinction by saying:

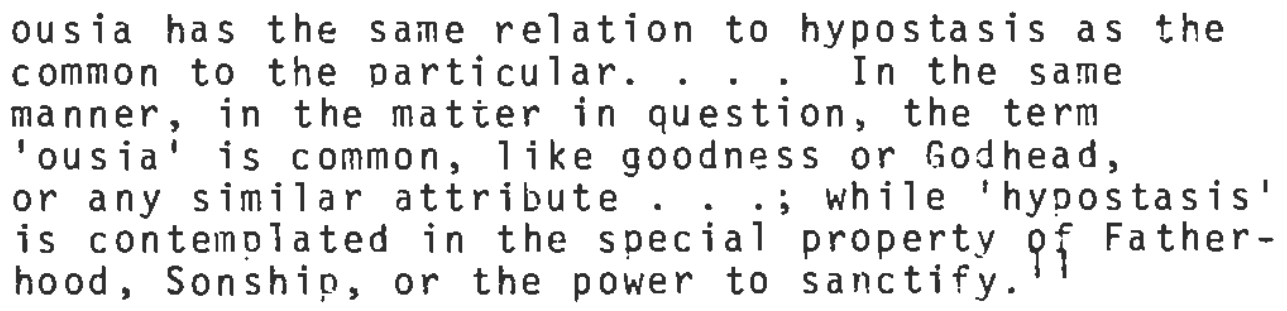

At this point, the church had reached a place of demarcation with the Greek terminology. From this time, hypostasis in

10 Bethune-Baker, Introduction, p. 237.

11 Epistle 24, in Bethune-Baker, Introduction, p. 238. 
the Greek mode of expression would mean the particular personal existence of Father, Son, or Spirit.

Apparently, this distinction was not entirely satisfactory to Augustine. He says: "I say essence, which in Greek is called ousia, and which we call more usually substance. They indeed use also the word hypostasis; but they intend to put a distinction, I know not what, between ousia and hypostasis." (V.8.9-10.) Perhaps Augustine was not fully apprised of the distinction made by the Greek terminology. 12 or, perhaps he was not convinced that the distinction made was a credible one. Regardless of the extent of Augustine's knowledge of the Greek sources, he was not enabled by the Greek terms to come to a satisfactory understanding of the unity of the Godhead.

\section{"Substantia"}

Neither did the traditional Latin term, substantia, prove to be completely satisfactory to Augustine. However, he does use the Latin term to fill the vacuum until he could establish a better understanding of the unity. For example, he says: "He who is God is the only unchangeable substance or essence, to whom certainly BEING itself, whence comes the name essence, most especially and most truly

12 pebate continues as to whether or not Augustine had easy access to the Greek materials. See Harnack, 4:132, and Teselle, Augustine the Theologian, p. 294. 
belongs." (V.2.3.) 13 In Augustine's understanding, there was a close parity between essence and substance, ousia and substantia, which is easily understood. substantia, the verbal noun from substo, means "that which underlies a thing" or "that by which anything subsists or exists" or "the essence or underlying principle by which each res is what it is."14 Only that which has real existence is "substance" and a fortiori, that which has real substance is substance. Yet there was even more confusion of terminology. In the Latin church, substantia was used to translate the hypostasis of the Greeks, and, with essentia, to translate ousia! Augustine expresses this confusion by saying: "that which must be understood of persons according to our usage, this is to be understood of substances according to the Greek usage; for they say three substances, one essence, or substance." (VII.4.8.) Terminology presented a definite barrier for the establishment of a clear apprehension of the doctrine of the Trinity. Confusion existed between the Greek and Latin terms, and within each language.

13 In V.9., Augustine says: "ut hoc intelligatur cum dicimus essentiam, guod intelligitur cum dicimus substantiam: non audemus dicere unam essentiam tres substantias; sed unam essentiam vel substantiam, tres autem personas."

14Bethune-Baker, Introduction, p. 231 . 
Augustine's Problems

If Augustine is to give a credible explanation of the unity of the Godhead, he faces two barriers. First, he has to resolve the terminological problems created by the disparity between the Greek and Latin words. Second, he has to extricate whatever term he uses from the Aristotelianism which certainly did accompany all language analysis.

Perhaps the first problem can be resolved, but some critics do not believe that Augustine was capable of avoiding the second problem. "God cannot be said to be a substance term," Durrant says, "in the sense that, granted its use in Christian thought, it cannot perform those rules or exhibit those features which Aristotle's substance terms do."15

\section{Augustine's Solution}

Augustine's solution resulted fram using substance in an "improper" fashion. (SEe VI.4.9. and 5.10.) By some it would be called an "illegitimate" usage of the term. 16 However, in Augustine's own words, "improper" is the suitable term to describe his usage of substance. "It is clear that God is improperly called substance, in order that He may be understood to be, by the more usual name essence, which he

150urrant, p. 71. Durrant claimis that substance, by definition, must be mutable.". . . anything falling under the category of substance admits of accidents; indeed it is parc of the very consept of substance that anything which falls under this caiegory should admit of accidents"; $p .121$.

$$
15 \text { Ibid., p. } 87 .
$$


is truly and properly called; so that perhaps it is right that God alone should be called essence." (VII.5.10.) 17 In De Civitate Dei, Augustine's tour de force appears candidly. He says there that "as from sapere comes sapientia, so from esse comes essentia, a new word indeed. . Which the old Latin writers did not use, but which is naturalized in our day, that our language may not want an equivalent for the Greek ousia." (XII,ii) Augustine makes the step to relieve the terminological confusion by excising substantia as the most proper term, and substituting essentia. Verbal coinage does not provide new concepts; this is not the point. However, to substitute the precise for the ambiguous helps demonstrate what is not being said.

However, it is by the purifying of essentia, or substantia, of its accretions produced by the categories that Augustine clinches the tour de force. By this purification of the concept, he separates the notion from all "accidents." Therefore, God can be considered as pure, unchangeable Being. Because he considers mutability as proper to Aristotelian substance, he realizes the abuse in calling God substance, or even essence if by essence one means merely what substance meant universally. (VII.5.10. and V.2.3.) As Tillich has rightly said, "God is 'summa essentia', ultimate being,

12". ..unde manifestum est Deum abusive substantiam vocari, ut nomine usitatiore intelligatur essentia, quod vere ac proprie dicitur; ita ut fortasse solum Deum dici oporteat essentiari." 
beyond all categories, beyond all temporal and spatial

things. Even the categories of substance cannot be used."18 Augustine, by creating a fundamental difference between his concept of essence and Aristotelian substance, transformed the notion, thus eliminating the idea of mutation.

Augustine says that "whether he be called essence, which He is properly called, or substance, which He is called improperly, he is called both in respect to Himself, not relatively to anything." (VII.5.10.) To have any real apprehension of the Beirig of God, there must be two levels of understanding of the notion of essence. There are, he says

- other things that are called essences or substances. . / whichT admit of accidents, whereby a change, whether great or small, is produced

in them. But there is not accident of this kind in respect to God; and therefore He who is God is the only unchangeable substance or essence, to whom certainly BEING itself, whence comes the name of essence, most certainly and most truly belongs. (V.2.3.)

Augustine argues that the things which change do not retain their own being; and that which can be changed, even though it is not yet changed, is able not to be what it is. For God to be and never not to have been, for Hirn to be unchangeable, Augustine is bound to say that there is no possibility of accident, whether separable or inseparable accident, as the Greeks distinguished them. (V.4.5.) God alone is the

\footnotetext{
I8pati Tillich, A History of Christian Trougnt, ed.

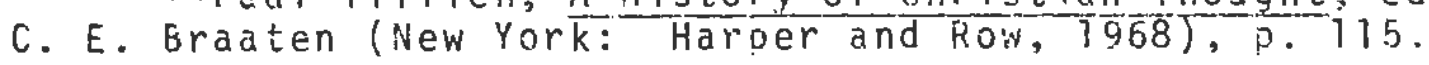


category of true and pure being. (V.2.3.) There is nothing accidental, nor is there the possibility of accident in God, because, a priori, there is nothing changeable concerning God, nor can anything be lost from His Being. (V.4.5.) He remains altogether what $H e$ is, and continues to be unchangeable as He always has been.

We pause to note what Augustine has accomplished. Confusion existed in terminology. Although he wavers between substantia and essentia, Augustine indicates that essence more properly describes the Being of God. Second, he does something radically different with the categories. Substance had been thought to be that to which something could be predicated, as accident. Aristotle's category of substance was restricted, by its primary definition, to the immanent; but Augustine applies it to the transcendent God. Augustine's reluctance to apply the word substance to God comes as a natural consequence of God not being the subject, in Augustine's opinion, of His own attributes; but rather what God has, He is. God is the only pure Being, because He is absolutely unchangeable and hence the only absolute Being.

\section{The Nature of the Godhead}

To what might that unity of essence or substance be likened? What is the nature of the unity?

Augusine's argument in Book VII betrays the influence of Aristotle's various kinds of unity in ousia. (VII.6.11.) 
It is not enough simply to say that Augustine lifts substance from the categories. He continues to wrestle with the possibility of using some of the previous understanding of ousia to conceptualize the nature of the unity of the Godhead. Harry A. Wolfson contends that Augustine chose as the best of the possibilities "a common underlying element. . . This is called unity of substratum." 19 Is Augustine satisfied with "substratum" as the most proper description of the unity? This is not a paltry question, because its answer underlies the whole concept of the unity of the Godhead. Previous to this point, we have discovered that Augustine considered the unity to be singleness of essence. Here the question concerns the bearing of the unity on the multiplicity. In Book VII Augustine considers three possibilities in the attempt to explain the unity. (VII.6.11.)

\section{(1) Genus and Species}

The first possibility is that the three Persons of the Godhead may be regarded as three species, and the one essence as one genus. Augustine reasons:

For if essence is the genus, and substance or person the species, as some think, then I must oinit what I just now said, that they ought to be called three essences, as they are three substances or persons. (VII.6.11.)

The example he uses to disentangle the problem of this terminology is that of horses, as analogous to species, and

19. Wolfson, pe. $350 f f$. 
animal as genus. 20 But since it is improper to speak of three horses as one animal, but rather they must be three animals, so it is impossible to speak of three species of the Trinity and only one genus, God. He uses the parallel: genus = animal/God; species = horses/Persons; therefore, as three horses are three animals, so three Persons of the Trinity would have to be three Gods. But this is the heresy of tritheism, and must be rejected. Thus, the first possibility is not a possibility at all.

(2) Species and Individual

The second possibility is that the three Persons could be considered as three individuals and the one essence as one species. The reasoning and the objections are parallel to those of the first possibility; here species and individual simply take the place of the genus and species in the previous example. He says:

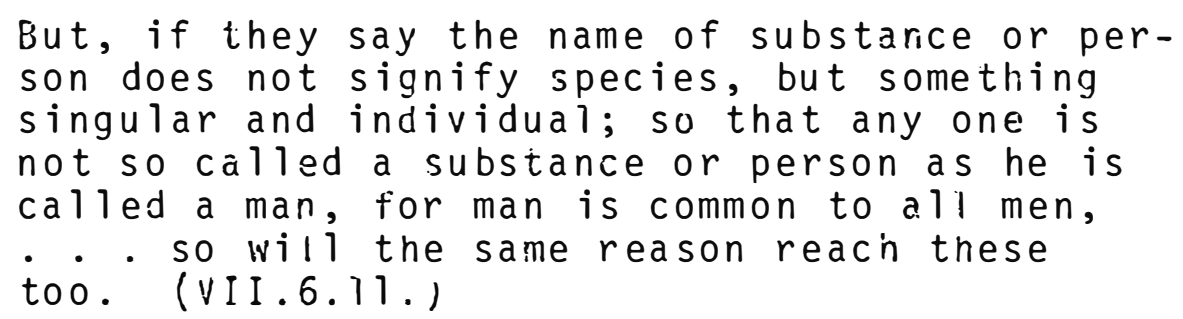

He uses as an example Abraham, Isaac, and Jacob as three individuais of the species, man. The implied argument would

20Altinough Augustine's intention may be obvious, the argument seems incoherent. Three horses are rot three species. 
be as before: species $=\operatorname{man} /$ God; individual $=$ Abraham $/$ Father, etc.; but as three individuals are three men, so three individuals of the Godhead would be three Gods. Again tritheism obtains, and this possibility must be rejected as being heresy.

\section{(3) Substratum}

In the third case, Augustine says that "we do not therefore use these terms according to genus or species, but as if according to a matter that is common and the same." $($ VII.6.11.) 21 The example he uses to express this unity, "as if according to a matter that is common and the same," is that of statues made of gold. In another place Augustine explains the gold illustration by saying that "if gold is the Father, gold is also the Son, gold also the Holy Spirit."22 The gold of the three statues could be the same gold, and each one of the statues would be gold; yet the gold would neither be genus to a species, nor species to individual statues.

Augustine ultimately rejects the example of gold, however, even though it would fit Aristotle's concept of

21 "Non itaque secundum genus et species ista dicimus; sed quasi secundum communem eamdemque materiam."

22 Enar. in Ps. 68, 1, 5; quoted by Wolfson, p. 351 . 
"substratum." It must be rejected because taking such an analogy literally will not do justice to the Trinitarian concept. Wolfson observes that Augustine definitely says that he "prefers" the analogy of substratum to that of species or genus as the common unity of the Trinity. ${ }^{23}$ However, Wolfson's assertion is only partially correct. He correctly realizes that Augustine chooses substratum as a better analogy than genus or species, but he does not then acknowledge Augustine's ultimate rejection of this analogy alsc. The obvious argument against the substratum analogy, an argument with which Augustine was no doubt familiar, would be: one could easily take the substratum, as in the example of the gold, to be a pre-existing material, which would have existence prior to the three statues. That is, God, thought of as the unifying substratum, could be thought of as existing prior to the three persons. There would be, therefore, a prior God, and three'persons, making four Gods! The three Persons, and the Godhead from which the three come, would all be God. When the implications of this analogy are considered, it breaks down just as the species and genus argument did.

Augustine admits the limitation of this analogy immediately after using it. (VII.6.11.) Substratum gives

23 wolfson, p. 326 . 
the impression that the many are formed "out of" the substratum, and this cannot be the case with the Trinity. He reasons:
We say three persons of the same essence, or
three persons one essence; but we do not say
three persons out of the same essence, as
though therein essence were one thing, and
person another, as we can say three statues
out of the same gold; for there it is one
thing to be gold, another to be statues. . .
But in the essence of the Trinity, in no way
can any other persons exist out of the same
essence. (VII.6.11.)

He proceeds to say that this is, in man's mind, a great

mystery. For the three Persons to be equal to each other singly is a matter which man cannot comprehend because bulk and space restrict human understanding of the three in one. 24

Substance transcendentalized does not fit the Aristotelian understanding of the first category. It does not have the same qualities because it is beyond the realm of all accident or change; it is beyond the material. W. G. T. Shedd calls the substance of the Godhead "Spiritual Substance." In the material realm, he argues supportatively with Augustine, for there to be three different forms of

240urrant says: ". . one would hardly expect

'God' in its Christian use to perform those

roles or exhibit those features which such sub-

stance terms exhibit, for lad is not part of

that scheme which such terms are an integral

part, namely the scheme of material bodies and

spátio-temporâl existents. . ."; p. 71. 
gold, there must be three different pieces of gold. Shedd says:

But spirit is not subject to the conditions of matter; and as the whole human soul may all of it be in every part, and every point of the body, at one and the same instant, so the Divine essence may all of it be in each of the three Divine persons simultaneously. It is no contradiction, taking the nature of unextended spiritual substance into view, to say that the one numerical Divine essence is indivisibly and wholly present at a million points of space at the same time, without making it a million of essences. 25

Shedd also applies Augustine's analogy of the mind. Three sjmultaneous forms or modes of existence do not necessarily imply three different minds or substances, as in the instance of mind or immaterial substance. "One and the same entire mind may remember, understand, and will simultaneously. Memory, understanding, and will are three simultaneous forms, or modes of one and the same mind or spirit." 26

Thus, it is understandable that there is another alternative to Aristotle's figures of unity in ousia. Augustine's concept is very similar to, but not commensurate with, substratum. When the one essence is said to be in three Persons, Augustine does not mean that essence is a fourth thing. A kind of spiritual substance must be understood, which does not have the qualities of bulk and space.

25williar G. T. Sheod, Dogmatic Theology, 2 vols., 3d ed. (New York: Charles Scribner's Sons, 7897), 1:298. 26 Ibid., p. 275. 
But this brings us to the next section dealing with some of the implications of the unity of the Godhead.

\section{Implications}

\section{(1) Interpenetration of the Persons}

"The simultaneous existence of the undivided and total nature in each of the three persons, the Nicene trinitarians endeavored to illustrate by the figure of circumincession. - : There is a continual inbeing and indwelling of one person in another." 27 It is this kind of interpenetration that Augustine maintains.

There is no substratum, not a three "out of" one, but a three "in" one, and one "in" three. We must keep in mind several propositions: for Augustine God is absolute Being, simple and indivisible with no accident nor change of any kind; He transcends the categories. With this starting point, Augustine could affirm an equality of the three. He considers it a matter of "catholic faith that the Father, and the Son, and the Holy spirit intimate a divine unity of one and the same substance ir an indivisible equality." (v.4.7.) With the numerical unity of the Trinity there is no division of the essence of God. The whole nature is one God, and the whole nature is in each of the divine Persons. The three have the same eternity, immutability, majesty and

$$
27 \text { Ibid., p. } 299 .
$$


power. (De Doctrina Christiana 1.5.) Thus each Person of the Trinity is God, and they are all together one God; each is the full essence, and all together are one essence. The divine essence with all the absolute perfection of the perfect God is identically the Trinity of Persons, and each of the three Persons. Augustine says:

But the Father and the son together are not more truly than the Father singly, or the Son singiy. Both together, therefore, are not anything greater than each of them together... And so the son and the Holy spirit together are just as great as the Father alone, since they are as truly. So also the Trinity itself is as great as each several person therein. (VIII.1.2.)

And, "in the highest Trinity one is as much as the three together, nor are two anything more than one. And they are infinite in themselves. So both each are in each, and all in each, and each in all, and all in all, ard all in one." (VI.10.12.)

To this thought of the inseparable intercommunion of the three Persons expressed by Augustine, theologians have applied the term Tepcxupyes The verb from which the term originates entails two senses: "to move" and "to contain." Both senses are included in the term; the Persons interpenetrate each other, and each contains the other. ${ }^{28}$ With this interpenetration. Augustine thus eliminates the remnant of subordinationism, and establishes more clearly and sharply

28 Bethure-Baker, Introduction, p. 226, note. 
the consubstantiality of the three Persons and the numerical unity of their essence.

What then is the nature of tne unity? It is not a generic unity, nor a unity of species, nor even a unity of substratum. The interpenetration of the three in one makes it impossible to chink in these terms. Although ic is a bic of a enigma, as Augustine admits (VI.10.12.), the Trinitarian nature is of spiritual substance, with three Persons completely penetrating one another, with the whole Being equal to each and each equal to the whole.

\section{(2) Trinality}

God is trinal, not triplex. This consequence hardly demands noting, for all that has been said previously expresses this concept; but it is a common problem involved in attempting to explain the Trinity, and Augustine deals with it. (VI.7ff.)

Victorinus had earlier suggested that God should be described as "threefold," or "triplex." This, quite naturally, would cause one to think of three individuals, and the problem of tritheism would enter again. 29 The triple is composed of three different substarices; it has parts, and is complex. Augustine argues that if God were triple, the Father alone, or the Son alone, or the Spirit, would be less

29J. W. D. Kelly, Early Christian Doctrines, 2d ed. (New York: Harper and Brothers, 1960), p. 273 . 
than two of the Persons together. But this cannot be the case because of the nature of the unity of the Godhead, which must be totally free from change. If addition could occur within the Godhead, God would be mutable. Therefore, there is not threefoldness or triplicity in God, but only a pure trinity. Triplex is an impossible term; trinal fits the occasion better. The trinal, however, is without parts, and is incomplex. It denotes one simple substance in three forms. Thus, Victorinus incorrectly regarded God as triplex; the better terin to use is trinal.

\section{(3) Operations ad extra}

Augustine insists on making all the divine action, ad extra, the work of all three persons indistinctly. From the oneness and identity of essence of the three divine Persons Augustine concludes that the Persons have, ad extra, but one will and operation. If the three have identically the same essence, the conclusion is that they can only nave one will and operation. He says: "The Will of the Father and the son is one, and their pperation inseparable." (II.9.) "When one of the three is mentioned as the author of any work, the whole lrinity is to be understood as working." (Enchiridion 38) "The catholic faith holds that the works of the father and son are not separable. . not only of the father and the Son but a? so of the Holy spirit... 
are the works inseparable."30 In relation to all of creation, the three work as "one principle." (V.14.15.)

Because of this premise, Augustine is forced, so he thinks, to take a unique interpretation of the theophanies of the $01 d$ Testament. The popular opinion had been that these theophanies were manifestations by which the Son alone had appeared to the patriarchs of $01 d$ Testament times. Augustine deduces that each of these manifestations is necessarily the work of the whole Trinity. He says that he cannot accept the opinion that some special Person of the Trinity appeared (II.15.26.), and therefore he concludes that "we must believe that by means of the creature made subject to Him, not only the Son, or the Holy spirit, but also the Father, may have given intimations of Himself to mortal senses by a corporeal form or likeness." (II.18.35.)

The natural question to arise, and one considered by Augustine, would be: does this ad extra action obliterate the several roles of the three Persons? Augustine denies this effect, as it was not that the Trinity was "born of the Virgin Mary, and crucified under Pontius Pilate. . . Nor again, that this trinity descended in the form of a dove upon Jesus. . . Nor yet that this Trinity said.. 'Thou art my Son'." (1.4.7.) While it is true that the Son, as distinct from the Father, was born, suffered, and

30 jo. tract. 20.3., quoted by Edmund J. Fortman, The iriune God (Philadelphia: Westminister Press, 1972), 
rose again, it remains equally true that the Father cooperated with the Son in bringing about the incarnation, passion, and resurrection. Only on the basis of the special manner in which each of the Persons possess the divine essence can the roles in the external operations, which are proper to the individual Person, be attributed to Him. The nature of each Person's origin makes certain attributes in external matters appropriate to Him. The later Latins used the word "appropriation" to express Augustine's idea. 31 That Augustine did not explain the theophanies of the $01 d$ Testament with the idea of "appropriation" is a mystery. Augustine, by using this concept later termed "appropriation," does not perform a unique service. Earlier, Basil had said that all things "'are performed equally among the worthy by the Father and the Son and the Holy Spirit' (Ep. 189.7.), and the Greek Fathers had also recognized that there is a unity of operation in God and had used it to prove the unity of the nature of the three." 32 Although Augustine's work in this area is not totally original, it does establish the precedent for the further discussion of the matter.

The works, individually, of the three are in no way a cortradiction to the cooperation of the working. The

31E. Portalie, A Guide to the Thought of Saint Augustine, trans. Ralph J. Bastian (Chicago: Henry Regnery Co., 1960), p. 132.

32 Fortman, p. 143. 
individual ascriptions of particular tasks are just notes of emphasis, indicating the Person through whom the external operations proceeded. All of the actions of the Trinity, whether they are commonly assigned to one Person or another, are the work of the Trinity.

(4) God is His attributes

In his Categories Aristotle attempted to make possible the definition of all that is. With God, however, there can be no such definition, because He is Being itself. No predicamentals, in the form of the Aristotelian categories, apply to Him. To express the notion of this important point in precise terms, Augustine formulated a doctrine which was to remain the permanent possession of Christian philosophy and theology. He says that God is what He has. 33 "He who is God is the only unchangeable substance or essence, to whom certainly being itself, whence comes the name of essence, most especially and most truly belongs." (V.2.3.) The proposition that God is His attributes follows naturally from the proposition that God is Being, with no change. That which can change cannot retain its being, since being in this sense is the transcendent Being which Augustine recognizes as the nature of God. Man, according to Augustine's idea, is not his attributes, but has them. Thus, the

33Augustine says in De Civitate Dei. XI. 10.3.:

"quae habet haec et est, e $\bar{t}$ ea omnia unus est." 
categories can be used to describe the nature of man and all creation, likewise; but these same categories actually cannot apply to God at all since He has neither strength nor wisdom nor any of His other attributes, because in $\mathrm{Him}$ they are one with His very Being. God does not have attributes; He is His attributes.

Augustine deals with a possible objection persisting in the understanding of the church of his day. (VI.I.1.) The problem was: If the Son, according to Paul, is the Power and Wisdom of the Father, is the Father Wisdom Himself, or only the father of Wisdom? ${ }^{34}$ If God is only the father of Wisdom, and Wisdom is the Son, there would be an inequality in the Godhead, according to Augustine. If it is the case that God is the father of Wisdom, then He likewise is the begettor of His own greatness, goodness, eternity, and other attributes. (VI.1.2.) But this argument is actually refuted earlier where Augustine proved that those attributes belong to the very essence of God. (V. 10.11.) In like manner as he has shown that there are not three essences, there are not three greatnesses, nor goodnesses nor eternities. As he previously explained that the substance of God is totally beyond the scope of Aristotle's concept of substance, likewise all the attributes of God are beyond the scope of the categories. They are not

34 I Corinthians 1:24: "Christ tine power of God, and the wisdorn of God." 
predicamentals, in the sense of the Categories. "Let the same be said also of goodness," he reasons, "and of the eternity, and of the omnipotence of God, and, in short, of all the predicamentals which can be predicated of God, as He is spoken of in respect to Himself, not metaphorically and by similitude, but properly." (V.10.1l.) His line of argument proceeds: Things partake of greatness, and it is therefore one thing to be, and another to be great, such as a great house, for example. The great house is not absolute greatness itself, but is great because of greatness. But there must be an absolute greatness by which all things that are great, are great. Augustine calls this greatness "primarily great." But if God were great with a greatness not Himself, there would be a greatness greater than God; but nothing is greater than God. Therefore, God must be great with that greatness by which He Himself is that greatness. Thus, it is the same thing for God to be, as to be great. This same conclusion obtains for the other attributes of God also; therefore, Jesus as Wisdom is not something different from the Father of Wisdom. Because God is the attributes which are spoken of $\mathrm{Him}$, He is Wisdom itself. Therefore, when Jesus is spoken of as the wisdom of God, it is not in a way in which the Father or the spirit are disassociated from being Wisdom. God, the Godhead, each of the three Fersons of the Trinity, is His attributes. 
Also, as a natural consequence of this principle, whatever belongs to the divine nature as such should in the most precise language be expressed in the singular, since that name is unique. Just as there is only one essence, there can only be one greatness, "for it is the same thing to God to be, and to be great." (V.10.11.) Therefore, again as a consequence, each of the three Persons is the attribute, and the Trinity itself is the attribute. The Son is the equal of the Father in all the attributes, as is the Holy Spirit; and yet there is not a plurality of essence. (VI. 3.4. and VI.5.7.)

As a concluding observation to the principle that God is His attributes, we note that Augustine rightly determines that there can be no addition to the nature of God. God is not like ordinary substances, e.g., Aristotle's substance, which does increase by addition, and decrease by subtraction. The problem involved is the concept of spatial or temporal substance, as opposed to the spiritual substance of God. Because God is spiritual, rather than spatial and temporal, it is nonsense to conceive of God growing by addition, or decreasing in any manner.

But a possible objection might be raised in the light of the Scripture's teaching that the spirit of man "is joined unto the Lord."35 However, perfection cannot increase. When the finite is joined to the infinite, there 
is no. increase in the infinite. "Our substance therefore is changed for the better when we become $\mathrm{His}$ sons; and $\mathrm{He}$ at the same time begins to be our Father, but without any change in His own substance." (V.16.17.) of course, it is with reference to the essence of God that Augustine makes this observation. It is not that there is a change in the essence of God by the addition of sons, but that the person himself, man, is changed. There can be nothing added to God, by definition. Perfection cannot be perfected.

\section{A Short Evaluation}

Perhaps at this point a few remarks on Augustine's concept of the unity of the Godhead would be appropriate, to summarize and prepare for the discussion in which he will attempt to deny the singularity in the Trinity.

"Never, up to this time, had the divine been set in relief so strongly in its relation to the three divine persons." 36 subordinationism, as a result, is dealt a severe blow by Augustine, and only occasionally raises its head in subsequent discussion within the church. Because of his unique method of beginning with the unity of the Godhead, Augustine rejected those distinctions which had previously been made between the Persons, such as in the ad extra actions. Because the older method had relegated to the different Persons of the Trinity different distinctive

36 portalié, Guide, p. 131. 
responsibilities, different worth values easily resulted. Augustine purified the concept of the Trinity from this possible error. Each Person of the Trinity is equal to the sum of the other two Persons in essence, and likewise the Trinity is equal to the essence of any of the three Persons. On the basis of this equality within the nature of the Godhead, there can remain no vestige of essential subordination. Of course, this great strength in reasoning also provides the groundwork for a possible weakness. The great unity principle could create real problems in the attempt to establish a viable understanding of what the three individuals can be. In simple terms, the more concrete the "one," the harder it must be to establish the "three."

Augustine's new starting point has yet to be rejected. Whereas, in the past, the mode of speaking would have been, "We believe in the one God the Father... and in our Lord, Jesus. . .",37 Augustine's great influence in this matter resulted in the new direction of the pseudo-Athanasian creed. This later creed begins: "This is the Catholic faith, that we worship one God in the Trinity and the Trinity in unity." Augustine's influence can hardly be denied. To use Bishop's words:

${ }^{37}$ The Nicene Creed. 
The Augustinian conception is distinctively static and logical, while the Nicene conception is evolutionary and genetic. The Augustinian conception dwells in the region of absolute being, far removed from those ideas of time and change and limitation from which the Nicene orthodoxy had such çßstant difficulty in guarding itself.

Augustine's progress beyond the Nicene formula established the precedent for conceptualizing the Trinity.

The positive assertion that essence must transcend the accidental predicamentals was also a strongly positive step forward in the Trinitarian discussions. As long as the nature of God remained, in theoretical analysis, under Aristotelian influence, progress in affirming the true nature of God was at a standstill. Augustine's transformation of the concept of transcendent substance, or spiritual substance, opened the way for his resclution of the problem of the predicamentals essential to God. God can be His attributes.

38 B ishop, p. 4 ? . 


\section{I I}

\section{AUGUSTINE'S REFUTATION OF "SINGLENESS" \\ IN THE GODHEAD}

For it must be devoutly believed, as most certainly known from the scriptures, and must be grasped by the mental eye with undoubting perception, that there is both Father, and Son, and Holy Spirit; and that the Son is not the same with the Father, nor the Holy Spirit the same with the Father or the Son. It sought then what three it should call them, and answered substances or persons; by which names it did not intend diversity to be meant, but singleness to be denied. (VII.4.9.) 1

\section{The Problem}

As Harnack observed, the crucia? point of Augustine's argument comes as he attempts to give credibility to the three in one, rather than with the one in three. Augustine's statement just quoted sounds a bit uncertain in what it intends; he is no more firm here than to indicate what he wishes to deny of the Trinity, that is, "singleness." But for the argument as a whoie to stand logical investigation, there must be a satisfactory analysis of what the "multiplicity" is, not just what it is not.

1". . Quaesivit qui tria diceret; et dixit substaritias sive personas, quibus ioninibus non diversitatem intelligi voilit, sed singuiaritatem noiuit. . ." 
As in the discussion of the unity of the Godhead, Augustine does not work in a void in attempting to explain the denial of singularity. However, Augustine's analysis begins first with the unity, and then seeks to explain the denial of singularity. The inherent danger of the earlier methodology is that of not getting beyond the three to establish the one, which would result, practically, in polytheism. The inherent danger in Augustine's method is that he will so firmly establish the one that trinality may be inconceivable. This is exactly the point of Harnack's accusation; he charges Augustine with not establishing the three. He indirectly accuses Augustine of modalism by saying: "We see Augustine only gets beyond Modalism by the mere assertion that he does not wish to be a Modalist, and by the aid of ingenious distinctions between different ideas." 2

Harnack is really quite subtle. He says that Augustine escapes heresy: (1) because he asserts that he does rot wish to be a modalist; (2) because ingenious distinctions between ideas are made. Harnack apparentiy thinks that Augustine was self-deceived because of his great desire to get beyond modalism; he was deceived because he thought that clever wording would establish the truth of his thesis.

2Harnack, 4:131, note. 
How clever Harnack is! The first reason he attributes to Augustine is, of course, of no value whatever. If the only reason Augustine can offer in his argument to deny singleness is that he does not wish to be a modalist, who will even listen to him? Harnack makes Augustine sound absurd, and thereby he prejudices the case against him. Merely to wish a conclusion does nothing toward assuring that conclusion. However, Harnack implies that Augustine uses linguistic maneuvers to achieve the desired end. But the second reason he attributes to Augustine need not be taken in this pejorative sense. No one can be confused by the intent of the word "distinction." Augustine does make distinctions in words because of distinctions in ideas. But the word "ingenious" is quite deceptive in the context. The word means: (1) having genius, having great mental ability; (2) clever, resourceful, original, and inventive. Now, what does Harnack mean? Was Augustine clever, original, and inventive? Or did he merely bend words to extricate himself from a logical trap? Only Augustime's argument itself can indicate the answer. However, let us be aware that what Augustine hoped has no bearing whatever on what he accomplished; that he would have wanted to escape modalism has no bearing whatever on whether or not he did escape it. Harnack's insinuation should not be allowed to prejudice the case. 
TeSelle claims that Gregory of Nazianzus was very helpful to Augustine by suggesting a way of developing the concept of the trinality. Gregory faced one of the Arian arguments, which could be stated in these terins: nothing can be said of God according to accident, since there can be no change in God; therefore, what is said of God must be said according to substance. Thus, the generated character of the son, and the ungenerated character of the Father, must be said to be according to substance; and this would make two different substances! Gregory rejected this opposition of substance and accident, and spoke of relation between the Persons of the Godhead. Analogously, a human father is father only in relation to the child, and not according to his being, as such. Likewise, the father of the Godhead is Father in relation to the Son; the Father is unbegotten in relation to the Son, and the Son is begotten in relation to the Father. ${ }^{3}$ Probably Gregory's concept did establish the foundation for Augustine's discussion of the "denial of singleness."

Augustine himself faced the Arian argument. He explains his situation by saying:

. among the many things which the Arians
are wont to dispute against the catholic faith,
they seen chiefly to set forth this, as their
most crafty device, namely, that whatsoever
is said or understood of God, is said not

${ }^{3}$ Eugere Teseile, Auqustine the Theologian (New York: Herder and Herder, $1970 \%, p p .294-296$. 
according to accident, but according to

substance; and therefore, to be unbegotten

belongs to the Father according to sub-

stance, and to be begotten belongs to

the Son according to substance; but to

be unbegotten and to be begotten are dif-

ferent; therefore, the substance of the

Father and that of the Son are different. $($ V.3.4.)

Augustine calls this argument a "crafty device," or, as an alternate reading, "a cunning dilemma." 4 Apparently the Arians were basing their argument on the Aristotelian scheme of categories. The distinctions in the Godhead, they granted, could not be according to accident, because God can have no accidents without entailing the destructive notion of change. But, their other alternative destroys the basic unity of the Godhead by demanding three substances. If a.b.c. are the Persons of the Godhead, and each is so distinguished as substance, then $a+b+c=3$ substances. Theirs is a valid argument, if one is willing to grant that there are only two possibilities of solution. Their argument is logical when it deals with the material things to which Aristotle's categories can be applied. However, neither of the alternatives could be satisfactory to Augustine. To escape polytheism, or modalism, he could only reject the two solutions, and offer a viable alternative.

As we did in the orevious chapter, we must deal with the terminological considerations proposed by the church 
fathers, and by Augustine himself, as he attempts to offer his alternative solution. In this denial of singleness, three words figure prominently: (1) person, (2) accident, and (3) relation. It is through the interworking of these three words that Augustine offers his alternative.

\section{The Terminology of the Trinality}

\section{(1) Person}

Augustine says that "when the question is asked, What three?, human 1 anguage labors altogether under great poverty of speech. The answer, however, is given, three 'persons', not that it might be (completely) spoken, but that it might not be left (wholly) unspoken." (V.9.) The word Augustine chooses to signify the "what three?" is "person." At least on the surface, several problems arise with this terminology. Augustine himself is not completely satisfied with the terminology; but he says here and elsewhere (VII.4.7-8.) that "person" is the closest approximation he can give to what the three are. To prevent silence in the matter, he must use the terms available.

The etymology of the word helps to understand the problem involved, and the subsequent acceptance of this word by Augustine with his limited approval of it. Twc words have to be considered, both the Latin "persona" and the greek "mpórwitor." 
Ipóowiter

The basic meaning of the Greek term is "face" or "countenance." 5 The connotation of the word did not include an individual, per se, as we would speak of an individual today; rather it meant the "appearance," "form," or "figure" of an individual. Because the mask worn by the actors in the theatre resembled the human face, it was called rpcownov. The word then assumed the meaning of the part played by the actor. Thus, quite early the word entailed the idea of the part played by the individual. Later the word assumed the sense of denoting a man in his official position in society. Here then the intent meant the "public role" of the individual. As a man filled certain societal functions, he assumed societal roles. Even later, perhaps under the influence of the Latin term, persona, the word was given a technical sense which became common in legal documents. The general use of the word, however, as it was used in the days of the early church fathers, was "face," or its equivalent, "presence." Kittel's Theological victionary of the New Testament contends that the church fathers aptly picked a word which had a wide range of meanings, which would be and subsequently was narrowed by the theological debate surrounding it, 6

5 Gerhard Kittel (ed.), Theological oictionary of the New Testament, trans. Geoffrey W. Bromiley lirand Rapids: Wm. B. Eerdniars Publishing Company, 1958), 6:768.

6 Ibid.. pp. $768-780$. 
Although the fathers no doubt did narrow the sense of the word in theological debate, the origin of the meaning of the word is quite important. The word, in its developing stages, connoted not the person, as individual substance, but rather the function, presence, role, or appearance of that individual.

\section{persona}

The Greek term is closely related to the Latin, persona. This word also connoted the idea of mask, role, or prominent personage. The word was employed to designate the man himself as far as he had this or that persona. Thus, slaves, because they did not possess any rights of citizenship, were not regarded by Roman law as having persona; they were "aprosopo;" or "personae carentes."7

Today we hear the term "person," and only approximate conceptually the original meaning of the term as it was known by the early church. We hardly consider the distinctions involved in the word in the early period. In contemporary usage, the concept has come to involve either: (a) reference to a particular body, or (b) reference to individual personality, or (c) both. To understand Augustine's usage, however, we must revive the meaning of the word in his day; we must not anaiyze his usage on the basis of our usage. To give Augustine a fair treatment, we

\footnotetext{
7Bethure-Baker, Introduction, p. 233.
} 
must keep in mind that the concept in his day connoted role, mask, or part played.

\section{Fourth Century Confusion}

Had Sabellius not entered the Trinitarian debate, perhaps Augustine would have had little trouble in assimilating "person" into his Trinitarian vocabulary. But Sabellius did a great disservice to the church by contributing to the confusion of the terms in the third century. He employed the word "person" in his modalistic system. He was concerned primarily with the unity of the Godhead, and allowed modalism to be his answer to the multiplicity question. For him, the Father, Son, and Holy spirit were different phases of the one divine essence. "He seems to have adopted the language of the church so far as to speak of three 'persons', using the term mpóowirox but in so different a sense. . that the word was altogether discredited in the East." 8 Sabellius remolded the term to fit his idea of expanding and contracting modalities. Because his "persons" were mere expressions of God which were manifested and then disappeared as God retained His original manifestation, the church rejected his idea of modalism as unsuitable. Because of Sabellius'distortion of the concept of the nature of God and his appropriation of mpówiter to expressicn his idea, the Greek church

\footnotetext{
${ }^{8}$ Bethune-Baker, Introduction, p. 105.
} 
rejected the term and adopted an entirely different word, ímootáocs.

However, in the latter part of the fourth century, the new term was not totally accepted by all the church. Augustine himself says: "They indeed use also the word 'hypostasis'; but they intend to put a difference I know not what, between 'ousia' and 'hypostasis'; so that most of ourselves who treat these things in the Greek language, are accustomed to say, piar oviocar, Tpecs ímootáoccs" (V.8.9.)

\section{Augustine and persona}

The state of confusion in the fourth century is apparent. Perhaps Augustine was not aware of the new development of the Greek terms; or perhaps he was not satisfied with the distinctions hypostasis allowed. For whatever reason, he chooses persona as a more suitable term to explain the "what three?" Augustine says that he was contented with persona, for the lack of a better term and for the sake of "convenience." (VII.5.10.) $)^{9}$ Yet, it was not totally satisfactory: ". . We wish some one word to serve for that meaning whereby the Trinity is understond, that we might not be altogether silent, when asked, what three, while we confessed that they are three." (VII.6.11.)

9iFortassis igitur commodius dicuntur tres persone ..." 
But to say that Augustine uses the word does not necessitate the assumption that he used it as it had always been used before. Augustine squarely faced several objections to this word, which caused him to tailor the word to fit the needs of his discussion. He acknowledges the first objection by saying: "For person is a generic name, insomuch that man also can be so called although there is so great a difference between man and God." That "person" connoted the generic could be quite misleading. Augustine is attempting to say three persons, yet only one substance; but to use a generic term for three somethings entails that the three are instances of some universal. At this place the same argument applies as the one in the last chapter dealing with ousia. Person, as a generic term, can hardly be acceptable. On the one hand, it is quite impossible to speak of three horses as one anima?; rather they must be three animals. Likewise, it is impossible to speak of the Father, Son, and Spirit as person; rather they would have to be three persons. Un the other hand, substratum is not a proper concept to apoly to the idea of person either, because, as in the example of the gold statues, it is one thing to be gold, and another to be siatues. As a generic term, "person" does not appropriately describe the "what three?" But the three do have an identity of essence. Adrittedly, the term is not entirely accurate in the 
situation, because "the supereminence of the Godhead surpasses the power of customary speech." (VII.4.7.)

Augustine must do the same kind of thing with "person" as he has done with "substance"; the term must be lifted from the limitations of the categories to be understood in anunextended or transcendent sense. The same possibility of criticism results in this situation, as it did with the lifting of substance to a spiritual substance. This is a concept the "natural man" does not comprehend, because "he cannot think except under the conditions of bulk and space, either small or great, since phantasms or as it were images of bodies flit about in his mind." (VII.6.11.) But a Trinitarian Person must be just such that it is not 1 inited to bulk or space. Augustine's "person" does not perfectly

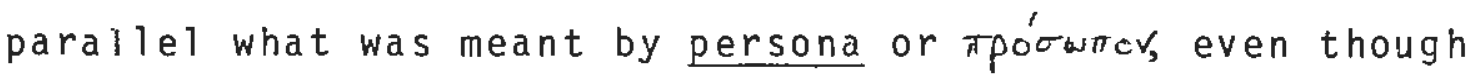
its notion is embedded in the terms. The word has taken on a new sense of its own. The concept is what W. G. T. Shedd calis an

* - incommunicable characteristic of the Divine essence, that . . . can subsist wholly and indivisibly in more persons than one. This distinguishes the Divine nature from the human. The latter can exist in more persons tinan one, but not as an "individual."... A trinitarian person is the entire Divine nature subsisting in a particular manner: viz, as Father, or as Son, or as Holy Spirit. 10

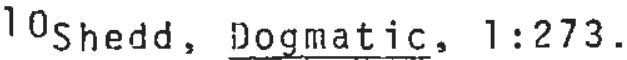


If one grants to Augustine the redefinition he gives to essence as a kind of spiritual substance, likewise his redefinition of person as a form of spiritual substance, in which there is simultaneous existence of the same divine essence, is credible. Either one must refuse to allow Augustine to make the step with substance, or the possibility of his tailored concept of person must be granted on the basis of the same kind of argument as with spiritual substance.

Shedd attempts to undergird Augustine's argument with a reference to Philippians 2. Although Augustine does not refer directly to this passage, it could be enlisted to demonstrate that the ingenious distinctions in concepts do have Biblical warrant. There is in Philippians 2 authority to describe the Trinity as spiritual substance, simultaneously existing in three forms. Paul portrays a Trinitarian Person as a "form of God." Because the Greek phrase is anarthrous, it cannot be the form of God, but rather a form of God.11 There is, then, the possibility of more than one form. There must be a difference between these forms and a material body, because it was only in the incarnation that one of these forms united with humanity. However, when this much has been said, the ranguage is found wanting in accurately depicting what the Person is like.

11 Ibid., p. 2.74. 
Although the analogies Augustine uses in the second half of De Trinitate are helpful in trying to conceptualize the three in one, ultimately they break down. No analogy from man's experience can properly depict how these three are one. Perhaps Augustine's most famous analogy is of the memory, understanding and love; yet there must remain the "I" to whom these three belong. A substratum or unifying element is required. Augustine nimself admits the flaw in the analogies. ( $X V .22 .42$.$) But that Augustine finds no exact$ parallel in nature for the three in one is no sufficient reason to renounce the logic of his argument. If one is willing to grant Augustine's presuppositions of the authority of the Biblical record, the concepts of the simplicity of the essence of God, and that God is Father, Son, and Holy Spirit, his deductions are quite sound. There are no parallels in the realm of the material world to describe that which is not bound by bulk and space. Therefore, Augustine is at liberty to redefine substance as spiritual substance, and person as the form of the "what three?" of the Godhead if the redefinition helps in understanding the concepts.

For one to reject the transcendent sense of substance and person entails making a categorical statement about reality, rether than examining Augustine's logical analys is of transcendental ideas. To dismiss Augustine's argument. on this basis would be to dismiss his assumption of Biblical authority. We are concerned to check his self-consistency, 
not to refute the authority he recognized in the Bible. That would be a wholly different, and perhaps more foundational problem to study; but it is not our topic.

Another kind of irrelevant criticism is that used by Emil Brunner, which seems to play on the emotion rather than the intelligence. He says that "we may order people to think thus: 'Thou shalt think these Three Persons as One', but it is no use: there still remains an uncertain vacillation between Tritheism and Monotheism."12 Brunner's argument deals with man's inability to conceptualize that which has no true material analogy. This is the kind of emotional abdication which must be avoided. Augustine has involved himself with a logical analysis; that it is difficult for man to conceive of three in one should be no reason to depreciate the argument. The self-consistent or selfcontradictory nature of Augustine's argument is the point of investigation, not the conceivability of it.

We take what Augustine has done with the concepts of person and substance as outstanding examples of philosophical theology. The doctrine of the Trinity is not expounded by studying the etymology of the technical terms alone. The technical terms observed apart from the context of Augustine's presuppositions hardly disclose his concepts. For Augustine, as it should be for all Christian

12H. Emil Brunner, Dogmatics. 3 vols.., trans. 01 ive Wyon (Philadelphia: Westminister Press, 1950), $1: 239$. 
philosophical theologians, the study of the notions must also take into consideration the sourcebook of Christian theology, the Bible.

(2) Accident

For Augustine, the three of the Godhead are called, with certain reservations, Persons. Once it is granted that Augustine has given a possible explanation of "what three?", there must 1 ikewise be a reasonable solution to such a question as: In what sense are the Persons distinct from one another? To say simply that there are Persons does not provide the answer to this question.

Augustine prepares the argument for his concept of "relation" as that sense, by eliminating the accidental as a possible solution. He says: "That which is accidental commonly implies that it can be lost by some change of the thing to which it is an accident." (V.4.5.) 13 Because of his adamant rejection of any mutation in the Godhead, Augustine must generate a concept free of accident, yet one which explains the difference between the three.

Accident received its common implication from the Aristotelian system. There are two possible ways of considering accident. An accident may be thought of as one of the predicables. There were five of these predicables

13"Accidens autem non solet dici, nisi quod aliqua mutatione ejus rei cui accidit amitti potest." 
for Aristotle: genus ( $y \in$ tos $)$, species ( $\hat{i} \hat{d}$ os ), difference ( $\delta$ caфopá), property (

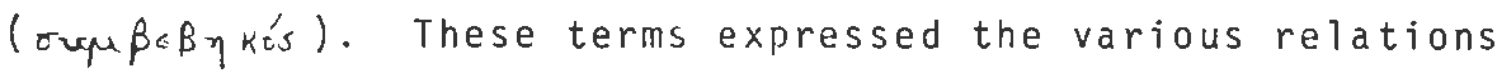
in which universal terms could stand to the subject of which they were predicated. In the Topics, Aristotle based his division of the predicables on the relations between subject and predicate. (I.C.8.) In this case, if the predicate is co-extensive with the subject, it gives the essence or property of the subject, as genus and species do. However, if the predicable is not co-extensive with the subject, it may be an accident.

Of course the accident could also refer to the ways in which man thinks of things, that is, as qualities predicated of substances. This case of accident would merely say that the accidentals are the categories which tell how substances actually exist.

Whether accident refers to the predicables or to the categories, Augustine must exclude them from all considerations of the nature of God. (V.4.5.) The Greeks had called some accidents separable, and some inseparable. (V.4.5.) ${ }^{14}$ These distinctions have no bearing whatever upon God's nature. Augustine argues that the feather of the raven is eternally black, as the Greeks would say, but oniy so long as the raven is. (V.4.5.) Although it remains black while the raver remains alive, upon the death of the raven the

14". . quàe graece appellantur axẃpco-ta. ." 
black feather ceases to be as the raven itself ceases to be. In the process of decay, even the "inseparable accident" vanishes. However, even though Augustine denies any accident to be true of God, whether it might be predicable accident or categorical, separable or inseparable, it is the accidental and not the predication that Augustine must eliminate.

If the predicate is co-extensive with the subject, it gives the essence or property of the subject. This kind of predication Augustine finds perfectly acceptable of God, because God is His attributes. These attributes are coextensive with God. Augustine grants that some things can be properly said of God because they are "essentially" true. Whatever is predicated of God according to substance is predicated equally and univocally of all three of the Persons. The Trinity as a whole, for example, and each of the divine Persons, is equally omnipotent and omniscient. 15 However, Augustine is also obligated to say that God is not the Father in the same sense that He is wise. If God is the Father $i r_{i}$ that sense, the following dilemma necessarily arises: God is wise as He is Father; therefore, "Fatherhood" is "essential" to the first Person--it is entailed in His essence." The logical result is that three essences are entailed, which Augustine denies. God is not Father

15Hodgson, Trinity, p. 149. 
according to a different consideration. Neither is God Father according to accident, because there can be no mutability in God. An accident is always a feature of a created thing, even if it is a permanent feature of a created thing, in which case it will eventually cease to be when the thing ceases to be.

Therefore, Augustine cannot speak of the difference in the three in terms of accident, nor can he refer to a difference in substance. One of the possibilities would entail mutability, and the other would make polytheism inevitable. Augustine has a better alternative.

\section{(3) Relation}

It is true that the more accurately the Godhead of both the Son and the Spirit was distinguished by the church, "the more important it became to determine exactly the relation in which the different persons stood to each other, and to the divine essence itself."16 When he has developed a satisfactory explanation of the essence, chosen "person" as the term to signify "what three?", and excluded any thought of accident, Augustine uses the term "relation" to make the distinct difference between the Persons. Yet, predicamental relations were defined as real accidents.17

15K. R. Hagenbach, A History of Christian Doctrines, 2 vols. (Edinburgh: T. \& T. Clark, 1883), 1:374.

17B. Mattingly, "Relation," Pek Catholic Encyclopedia (New York: McGraw-Hijl Eook Company, 1967), $12: 217$. 
But because there can be no change in God, the term "relation" cannot be allowed to apply to God in the accepted, predicamental sense. What Augustine must do with the term is the kind of thing he did with essence and with person. As with the other two terms, "relation" is "lifted out of the set of categories applicable to finite being alone, for the relations among the persons of the Trinity, since they are not changeable, are not 'accidents'."18 As Augustine says:

. . in God nothing is said to be according to accident, because in Him nothing is changeable; and yet everything that is said, is not said according to substance. For it is said in relation to something, as the Father in relation to the Son and the Son in relation to the Father, which is not accident; because both the one is always Fatherg
and the other is always the Son. (V.5.6.)

\section{A Redefinition}

Augustine redefines $\in$ ssence, person, and relation by removing them from the immanence-bound categories, and applying them to the transcendent Godhead. He is constantly aware of the imcomprehensibility of God, and therefore of the inability of "natural man" to understand fully the transcendent. (VII.6.12.) Bulk and space affect man's understanding. Because God is not bound by material

\section{8тeselie, p. 296.}

19". . dicitur enim ad aliquid, sicut pater ad Filium, et Filius ad Patrem. quod non est accidens." 
qualifications, Augustine does not feel constrained to use purely materialistic language when he considers the nature of God.

What then is predicated relatively of the three Persons severally? Paternitas and filiatio, fatherhood and sonship, are obviously two. A third is that the spirit is referred to as the "gift." The use of "gift" apparently caused some to err in understanding, and Augustine attempts to remove the confusion from the concept. If the spirit is described as gift, it could look as though the personhood of the spirit were contingent upon that which happened in time, because must not a gift have a recipient? Here a distinction in "relation" does have to be made. He says that:

Whereas, in the same Trinity, some things severally are specially predicated, these are in no way said in reference to themselves in themselves, but either in mutual reference, or in respect to the creature; and therefore, it is manifest that such things are spoken relatively, not in the way of substance. (V.11.12.)

Therefore, there are two ways in which relation might be applied: within the Trinity (ontologically), and to the creation.

\section{(1) Ontological}

Within the eternal Godhead, there is relationship, as the term refers to the difference in the Persons. "The Son never ceases to be the Son,. . because the Son was always born, and never began to be the Son." (V.5.6.) It is only 
in relation to the Father that the Son is so designated in the Trinitarian distinctions; and it is only as the Father is related to the Son as a father that $H e$ is so called. The Father is not so called in relation to Himself, nor is the Son called the Son in relation to Himseif. If this were the case in either situation, it would be the case in both situations and also as a concept would apply to the spirit. If it were the case for the three, each would be so called according to substance, because there would be a fundamental difference in the three according to the nature of each. If the difference were according to nature, that is, substance, there would be three substances, and therefore three Gods would be the consequence. Of course this would be an impossible option. Therefore, it is only as the terms are used "reciprocally and in relation each to the other" that they apply. (V.5.6.) Likewise considered must be the terms "begctten" and "unbegotten."

Augustine deals extensively with this "relation" theory. (V.6.7., /.8., etc.) The argument itself appears sound, but there is a weakness in expression because in "relative things that are reciprocal, names are sometimes wanting." (V.12.13.) Although one can speak of the Holy Spirit of the Father, the reciprocal is not properly the case; that is, the Father is not the Father of the Holy spirit. Or, for example, the spirit is the spirit of both the Father and the Son, but the Son is not the son of the 
Holy Spirit; He is the Son of the Father, exclusively. This is just the inadequacy of expression which Augustine has to admit. "For it is the case in many relatives, that no designation is to be found by which those things which bear relation to each other may (in name) mutually correspond to each other." (V.12.13.) That the spirit is "gift" must have caused some to ask whether the spirit was "gift" before as well as after He was given. The language must be examined closely. Augustine concludes this way: "For a gift may exist even before it is given; but it cannot be called a thing that has been given unless it has been given." ( $V$. 15.16.) The point of this explanation is that within the ontologicai Trinity, relations persist; or, to use Rabbi Duncan's coinage, the relations "intersist." 20 Although the relations may not always have expressions to explain adequately the distinctions between the Persons, the relations still exist, and continue to exist.

\section{(2) Economic}

This brings us to the second degree of relation, as Augustine uses it in regard to creation. Nothing can be said of God in time as accidental, but only as relative. As concerning the designation of the spirit as "gift," it

20Jorn (Pabbi) Duncan, Coiloguia Peripatetica, ed. Willian kight, 6th ed. Eü inburgh and Lindon: OTiphant, Andersor, and Ferriein. 1907$), p$. 128. 
is a gift eternally but a thing that has been given in time; likewise, for the Son to be Lord is descriptive of the relationship with creation, ". . For the creature is not from all eternity of which He is the Lord." (V.16.17.) At any point in which the change takes place in the relationship of man to God, or of any part of creation to God, the change is in the creation, and not in God. A prime example is man's conversion, and new sonship in christ. When a man comes to be a servant of God, Christ begins to be called savior in this relative sense. God is savior in relation to the creation. This kind of illustration is used by Augustine to explain that even in respect to creation, God does not change. It is man himself who is changed, and God becomes father to man when the heart of man is made new. Anything that is said concerning the association of the Persons of the Godhead, per se, which is not said of the Godhead according to substance, is said of that Person in relation to anocher of the three; anything that is said of God, or either of the three Persons, concerning His association with changeable creation, is said of Him in relation to the creation. In neither case does god or either of the Persons change; the distinction is made by a relationship, with the creation changing in the one case, and an eternally existing and unchangeable relationship in the other. 


\section{$\underline{\text { Implications }}$}

There are numerous implications of these theories of relation, accident, and person in Augustine's discussion. Some of the important ones are:

\section{(1) God Cannot Increase}

There can be no addition to God. Actually this concept was expressed in some detail in the last chapter. But let us consider this problem: How can Augustirie envision the incarnation, in which the Son took to Himself a true body and reasonable soul? Apparently this would be an addition to the Godhead, because it is the assumption of something not intrinsic to the second Person of the Trinity. If the incarnation were an addition, then God is mutable; but mutability must be denied by Augustine. What then is the solution?

In Book VI, Augustine explains the concept that "Dei natura nulla fit accessio." A distinction must be made between the normal mode of thinking and the mode of thinking required to conceive of the spiritual, transcendent realm of the Godhead. In the material world, bodies increase by union of themselves, and the same bodies can decrease by separation. But, when the material is joined to the spirituai, one cannot imagine that the spiritual increases. "For in those things which are not great by bulk, to be greater is to be better. . but yet the Lord does not therefore become greater . . . perfectness cannot increase." 
(VI.8.) When the Son became man, nothing was added to God because to unite an imperfect with perfect in no way perfects nor increases the perfect. God cannot become more perfect; He is perfect already. It is not, therefore, an addition to His nature to take to Himseif the form of a servant, as Paul says in Philippians 2. Therefore, God plus the human nature of the incarnate christ is not greater than God minus the human nature prior to the iricarnation. The incarnation added nothing to the second person of the Trinity. Even the incarnation, then, is not a true counterexample to Augustine's notion of the immutability of Eod.

(2) Relative and Essential Attributes

Some attributes of God are relative attributes, and some refer to His nature. (VII.2.3.) This point expresses the difference between those attributes which apply to the relation of the Persons to each other, and as regarding the essence of the Godhead. Two examples are used by Augustine to explain this difference: (a) some of the attributes are similar to wisdom. Both the Father and the son are together one wisdom, as they are one essence. No distinction can be made between this attribute and the one essence. Whether one thinks of the Father or the son or the spirit or the Godhead, it is the same for each or all to be, as to be Wisdom. (b) However, such is rot the case concerning the attributes which apply to the different reiations of the Trinity. Uniy the Son is the word, ard not the Father 
nor the Spirit, "for He is understood to be that Word relatively, but wisdom essentially." (VI.2.3.) Thus, some things predicated of God must be considered predicated of the different Persons. Some things attributed obtain from relational differences.

\section{(3) $3 \neq 1$}

In the Trinitarian distinctions, Augustine does not imply, as some might think, that $1=3$, and $3=1$. For such to be the case, of course, would be a logical contradiction, and certainly not what Augustine intends. If such were the case, Augustine's argument would certainly suffer Harnack's intended censure of being merely word bending. However, this is not the case. What Augustine does mean is that $r$ hat is three in one respect, is orie in a different respect. He does not attempt to say that three beings are one being, nor that three persons are one person. The better way of understanding the trinality and unity would be as three in one, and one in three. As there is but one essence, the Godhead, there are three Persons who have relative and personal characteristics.

If this is the correct interpretation of Augustine's logical analysis, then his statement of the Trinity is not self-contradictory. He asserts only that the same God who is one with respect to His essence, is three with respect to the internal distinctions of that essence, or with respect to modes of His Being. 
Is this credible? The possibility of it cannot be denied without assuming either that the spiritual world does not exist, or that it cannot be known, or that the human mind is in all respects the measure of the divine. Conybeare has said of the distinctions in the Godhead: ". . though we cannot precisely determine what those differences are, we have no more reason to conclude them impossible, than a blind man hath to conclude the impossibility of colors because he cannot see them." 21

(4) Quasi-Subordination

There is no subordination within the Godhead, except perhaps concerning the "relations"; and the concept of subordination can be used only when it is used very carefully.

There is an absolute equality among the divine Persons in respect to the essence which they are, and all are alike infinite and perfect in that essence. Augustine says that "if the Son were not equal to the Father, He would not be the 'son' of God." 22 The relations of the Persons of the Trinity, therefore, are not designations of degree of perfection or essence. Thus, when one speaks of the first or second or third Person of the Trinity, he uses these terms to apply to the relationships or simple numerical order of the Persons. These terms do not imply any kind Miracles.

21 shedd, Dogmatic, 1:268-269, auoting Conybeare, on. ${ }^{22}$ sermon 140, 5, quoted by Shedd, Dognatic, 1:301. 
of priority either of nature, substance, existence, or excellence.

However, as a relation the Sonship is subordinate to the Fatherhood because the begettor is the cause of the begotten; but again this distinguishes no degree of value or quality within the Godhead. "The Father stood above the Son and the spirit in this that he alone is of no other, but is absolutely original and independent; while the son is begotten of him, and the Spirit proceeds from him, and proceeds from him in a higher sense than from the son."23

Again, the functions ascribed to the Persons of the Trinity in the redemptive process express a kind of subordination. The Father comes first, and then the Son, and finally the spirit in the operation of God as redeemer. The Father sends the Son who purchases redemption, and the redemption is applied to man by the work of the spirit. However, this in no way violates the basic, "essential" equality of the Persons of the Trinity. To say that they function in a certain order in creation and redemption makes no qualitative judgment concerning the essence of the Persons.

If Augustine uses the concept carefully, he can say that a kind of subordinationism does exist between the Trinitarian Persons, and as the Persons relate to creation, especially to man. If he uses the termin this sense, as a

23philip Schaff, History of the Christian Church (Grand Rapids: Wm. B. Eerdmans Publishing Company, T964), $2: 685$. 
relative subordination, these distinctions in no way violate the Augustinian principle of three in one and one in three.

\section{A Short Evaluation}

As must be apparent by this time, Augustine did something quite radical with the Trinitarian discussion by moving several aspects of this discussion to an altogether new language 1 evel. That the three Persons of the immutable Trinity are different concerning "relations" moves the concept of relation beyord the boundaries of bulk and space. The differences within the Godhead obtain only because of distinctions of relation, either ontologically or economically. A similar thing was done with essence and Person, as he did with relation. In so moving the discussion to this new level of language, Augustine produced an important result: he was enabled to talk meaningfully about God both as unity and trinality without lapsing into self-contradiction. By raising the level of language to fit the Bihlical description, Augustine was able to extricate his argument from subordination in the Arian sense of the term. According to the predecessors of Augustine, the Father was the cause of both (1) the existence and (2) the Godhood of the other two Persoris. Augustine, however, improved upon this understanding: the Father did not make them God, but the Son stands in relation to Him as "begotten," as the Spirit is "spirated." Thus, from Augustine's point of view, as one 
discusses the denial of singleness of the Trinity, the marked emphasis on the unity of the essence can also be maintained throughout. There is no difference in the essence of the Father, Son, and Spirit; it is the same essence. The Godhead is in the form of three; the three are the Godhead. The relationships, as the Son begotten or the Spirit spirated, make no inequality within the Godhead. Only as the Son is Son in relation to the Father is the Son begotten. Thus, the terins designate a relation; but, as Augustine argued, it is an eternal relatiorship.

As several critics have indicated, Basil had already described the differences among the three Persons in terms of causal relation, and even used this argument against the Sabellians. But it was Augustine's strong emphasis on the distinctive divine relations which became the terminus a quo for the subsequent Trinitarian discussions. Augustine's discussion of the Trinitarian Persons makes it all tut impossible to think of God without thinking of Him as Father, Son, and Holy Spirit. Subsequent history validates this fact. Wrereas the earlier fathers had sought to find a unity to ericompass the three, and actually failed, Augustine succeeded in attempting to express the unity first; then the Trinality became his object of concern. When he had suificiently estabi ished the unchangeable, "essential" urity of the Godhead, of course the real problem was the Trinality. But it is to Augustine's great credit, 
86

and to the great benefit of the church through the ages, that he gave an acceptable explanation of the relations of the three Persons. In so doing, Augustine overcame both the monarchial and the polytheistic tendencies by admitting the inadequacy of human language, and working from that point. 
CONCLUSION

In the introduction two criticisms were mentioned of Augustine's De Trinitate. Harnack called the linguistic distinctions "sacred paradoxes." Another critic, L. L. Paine, described Augustine's logical analysis as jumpingjack logic. We acknowledged that these criticisms would have to form the crucible for the analysis of Augustine's success or failure in De Trinitate. That Augustine and his work on the Trinity have been greatly acclaimed by the church until this day is not a sure sign that his efforts in De Trinitate are significantly accurate. Church approval does not entail logical accuracy. The only true basis upon which Augustine's work can be evaluated is to determine whether he consistently avoided the pitfalls of modalism and polytheism, while offering a sufficient answer to explain how one God can be Father, Son, and Holy spirit.

\section{Linguistic Analysis}

If there is ingenuity in Augustine's De Trinitate, it is the way he used linguistic analysis to his advantage. Actually fugustine stripped the terms which must be used to discuss God and the Father. Son, and Spirit, of the things which cannot be said of God. 


\section{(1) Substance}

Augustine eliminated from the concept called "substance" the predicamentals implied by the material world. He explained the concepts in terms of transcendent substance, or as Shedd called it, spiritual substance.

By his analysis of the term, Augustine removed at least three problems from the discussion. First, he eliminated the terminological confusion. Although Augustine was willing to use the word substantia, he said that essentia would better suit the purpose in hand. By changing the established Latin terminology, apparently he was attempting to draw a distinction between the accepted idea of substance, and the only notion that can describe the Being of God. Thus, previous confusions were excised by Augustine's redefinition of the concept as essentia.

A second problem resolved by the lifting of substance to the realm of the transcendent was that Aristotelian connotations were eradicated from the concept of pure essence. The connotations which could not be allowed in the discussion of the nature of God were those describing accident, or change. Because God is immutable, nothing can be said of His Being which implies mutability. By their very nature, the Aristotelian terms of the Categories were devised to separate 1 inguistically the predicamentals which describe things as they are. Therefore, because of the very intent of the Aristotelian categories, they could not 
be used in an accurate description of the nature of God. By 1 ifting essence, or substance, from the context of changeable reality, Augustine conceived of essence, or pure reality, beyond the predicamental categories. However, he did not attempt to say that essence is a term with no predicamentals. Only predicamentals connoting mutability were removed. Those predicamentals true of the Being of God, are His Being. They are not qualities which can increase or decrease; they are true of His nature.

A third problein eliminated by the transcending of essence was the idea of subordination within the ontological Godhead. Various churchmen had mistakenly thought that there was an essential difference between the Son and Spirit, and the Father. Although the church councils had repudiated such an idea, the correct manner in which to understand the precise relationship of the three had to be explained. Augustine's strength was also the occasion for the possibility of weakness in the matter, however. He emphasized the one pure, spiritual substance, and thereby destroyed any possibility of an essential difference in the Father, Son, and Spirit. But in so emphasizing the unity, Augustine suggested the occasion for future criticism. The more concretely the unity is affirmed, the more difficult it must be to give a credible explanation of the trinality. For this very reason Harrack indirectly accused Auglistirie of slipping in to modalism. 
(2) Person

Augustine transcendentalized the notion of person also, to eliminate from it concepts not appropriate of the three individuals of the Godhead.

Augustine's sense of the term "person" is similar to, but differs in several aspects from the Greek Ipóownovand the Latin persona. Augustine's "person" did not suffer under the ideas of mutability as did the vernacular of mpeowrod and persona.

By the use of "person" in his purified sense, Augustine was enabled to say three somethings, but three in a different sense than the one essence. Therefore, there are three Persons in one essence, but the one and the three are not said in an equivalent sense. The numerical solution is three in one and one in three. True and permanent distinctions were then made credible by this usage of person.

\section{(3) Relation}

The other concept to be lifted from the categories of predicamentals was "relation." The relation of the Categories entailed the notion of change; but since this is a false idea in speaking of God, it had to be barred from the discussion of the nature of the Father, Son and Spirit distinctions.

Two kinds of relations were established in considering the Godhead. some of the relational distinctions apply to the ontological Trinity. The Son is son eternally, but 
only in relation to the Father. The distinctions imply no essential difference, but only a relational difference. Eternal relations of the three distinctions express the justification for saying there is a trinality of persons and a unity of essence.

Relations also exist in the economic Trinity, the Trinity as it expresses itself ad extra in creation and redemption. The Son is savior of God's elect only in relation to the creation. No qualitative or quantitative difference enhances or decreases the nature of the Son in His relation to creation; it is man who changes to become the servant of God. Thus, no change takes place in the Persons of the Godhead.

As a result, Augustine's "relation" is used analogously to the relation of the Categories. But, Augustine redefined it as he redefined substance and person.

The Real Point of Criticism

The linguistic analyses, in themselves, are not the real points of criticism of Augustine's De Trinitate. The fact that Auglistine remaved the notion of mutability from words normally conceived of as descriptive of the mutable world is indicative of the real points of difference in Augustine and some of his critics, and is indicative of the real point of his argument which must be assessed to determine the sirength or weakness of his notion of the Trinity. 
Durrant says that it is impossible to accept Augustine's ideas, because God, in Augustine's sense of the word "God," cannot perform those rules and exhibit the features of material language. 1 Durrant helps here by indicating that there is a presuppositional difference in his and Augustine's understanding of what "God" can and cannot be. The basic question then is what presuppositions one is willing to acknowledge and accept for the sake of discussion.

\section{The Presuppositional Differences}

(1) If one grants Durrant's view, either of two alternatives becomes obvious. Either the non-material, purely spiritual world does not exist at all, or our language is completely unsuitable to discuss it. In the first instance, the term "God" is completely void of meaning; it must be purely mythological. In the second instance, one may grant the possibility of "God," but nothing whatsoever can be said of Him. God in this case would be completely beyond the descriptive abilities of mar. No humanly conceived representation of God could be true in any way. Unly silence of the spiritual realm could be the result.

(2) If one grants Augustine's view, there is an authoritative description of the nature of all reality, the Bible. Therefore, on the basis of the Bible's authority,

1Durrant, B. 71 . 
God does exist as a unitary Godhead, but also as Father, Son and Holy Spirit. Man must then attempt to describe reality, the spiritual as well as the material or scientific, as well: as possible. Linguistic difficulties must be admitted, as Augustine did admit. The insufficiency of scientific analysis and description must be granted also. With the limitations acknowledged, however, man must tailor his language to fit reality.

(3) However, this raises the question of the purpose of language. That Augustine was inclined to mold his language to reality brings into relief another way of looking at the criticism of Augustine's work in De Trinitate. Certainly reality is not known independently of language; yet language may distort the view of reality by inaccurately portraying it. Augustine refined his language to portray reality. Apparently, Durrant is not willing to have language fit the nature of reality. Apparently, the Aristotelian categories must determine the nature of reality. How naive this approach sounds. Words are certainly functional, and not determinative. Reality must be described, not determined, by language. If the view of language which determined Augustine's freedom to fashion words to describe reality is accepted, his discussion does not lapse into sacred paradoxes, and his analysis is not jumping-jack logic. By very intricate and ingeniaus distinctions in concepts, Augustine attempted to do what language can only do in an analogous fashion. 


\section{An Evaluation}

Augustine made no pretense of giving a scientifically demonstrable understanding of the Trinity; he did not attempt to prove the Trinity at all. Rather, he worked from his basic frame of reference, acknowledging that faith precedes knowledge. Therefore, he attempted to give a more credible explanation of that which faith affirms. The view of reality projected by the Bible was, for Augustine, the true projection, and the scientifically demonstrable was not all of reality. The spiritual world beyond bulk and space likewise exists. From this assumption, he attempted to explain as understandably as possible that which was bel ieved.

Therefore, if one expects De Trinitate to be a testable proof, it fails miserably. However, if one grants the possiblity of a triune God, Augustine's work is most helpful in understanding the nature of that God. 


\section{SELECTED BIBLIOGRAPHY \\ Primary Sources}

S. Aureli i Augustini, De Trinitate, in Patrologiae, Series Latinae, Accurante J.P. Migne, Patrologjae Latinae Tomus XLII. S. Aurelius Augustinus, 1886 , pp. 8211098 .

St. Augustin, on the Trinity, trans. Arthur West Haddon, revised with introductory essay by William G. T. shedd, in Vol. III of A Select Library of the Nicene and Post-Nicene Fathers of the Christian Church, ed. Philip Schaff. Buffalo: The Christian Literature Company, 1887, pp. 1-228.

The Student's 0xford Aristotle, trans. under the editorship of W. D. Ross, Vol. I. London: Oxford University Press, 1942.

\section{Secondary Sources}

Ackrill, J. L. Aristotle's Categories and ne Interpretatione, Translated with Notes. Oxford: Clarendon Press, $196 \overline{3}$.

Allan, D. J. The Philosophy of Aristotle. London: 0xford University Press, 1952 .

Altaner, 3. Patrology. New York: Herder and Herder, 1950.

Anscombe, G. E. M. and Geach, P. T. Three Philosophers. Ithaca, New York: Cornell University Press, 1967.

A.rmstrong, A. H. An Introduction to Ancient Philosophy. 3d. ed. London: Methuer and Co., 1957. - st. Augustine and Christian Platonism. n.p.: Vilianova University Press, 1967.

Aveling, Francis, "Quantity," The Catholic Encyclopedia, Vol. XII. New York: The Catholic Encycropedia Press, $1911 \& 1913$.

Bambrough, $R$, ed. New Essays on p?ato and Aristot]e. London: Routledge and regan Fau 1955. 
Bardy, Gustave. Saint Augustine. Paris: Desclee, De Brouwer, 1940.

Barth, Karl. Church Dogmatics, Vols. II and IV, trans, and ed. G. W. Bromiley. Edinburgh: T. \& T. Clark, 1961.

Battenhouse, Roy W., ed. A Companion to the Study of St. Augustine. New York: Oxford University Press, 1969.

Bavinck, Herman. The Doctrine of God, trans. William Hendriksen. Grand Rapids: Wm. B. Eerdmans Publishing Company, 1951.

Berkhof, L. The History of Christian Doctrines. Grand Rapids: Wm. B. Eerdmans Publishing Company, 1953. Eerdmans Publishing Company, 1965.

Bethune-Baker, J.F. An Introduction to the Early History of Christian Doctrine, 9 th ed. London: Methuen

. The Meaning of Homoousios, Vol. VII of Cambridge Texts and Studies. Cambridge: The University Press, 1901.

Bishop, W. S. The Developrient of the Trinitarian Doctrine in the Nicene and Athanasian Creeds, A Study in Theological Definition. New York: Longmans, Green and Co., $19 \overline{10}$.

Bonner, G. St. Augustine of Hippo. London: SCM Press, 1963 .

Bourke, Vernon J. Augustine's Ouest of Wisdom. Milwaukee: The Bruce Publishing Company, 1945.

- Augustine's View of Reality. n.p.: Villanova University Press, 1964.

Breckinriage, Robert J. The Knowledge of God, Objectively considered. New York: Robert Carter Brothers, 1858 .

Brown, Peter. Augustine of Hipgo. London: Faber \& Faber, 7967 .

Brubier, H. Emil. Dogmatics, Vol. I trans, olive Wyon. Philadelphia: Westminster Press, 1950. 
Calvin, John. Institutes of the Christian Religion, Vol. I. Philade1phja: Westminster Press, 1960.

Cantwell, Laurence. The Theology of the Trinity. Cork: The Mercier Press, 1969.

Carré, Meyrick Heath. Realists and Nominalists. London: 0xford University Press, 1946.

Cayré, F. Manual of Patrology, Vol. I, trans. H. Howitt. Paris: Desclee and Co., 1936.

Chabannes, Jacques. St. Augustine, trans. Julie Kernan. Garden City, New York: Doubleday, 1962.

Copleston, Frederick. A History of Philosophy, Vols. I and II. Garden City, New York: Image Books, 1962.

Cunningham, William. Historical Theology, Vol. I. London: Banner of Truth Trust, 1960 .

Dabney, Robert Lewis. Syllabus and Notes of the Course of Systematic and Polemic Theology. 5th ed. Richmond: Presbyterian Committee of Pubijcation, 1871 .

D'Arcy, M. C.; Gilson, Etienne; et. al. A Monument to Saint Augustine. London: Sheed \& Ward, 1945.

Dick, John. Lectures on Theology, Vol. I. New York: M. W. Dodd. 1846 .

Dorenhemper, M. J. "Person in Theology," New Catholic Encyclosedia, Vol. XI. New York: McGraw-Hill Book Company, 1967.

Dorner, J.A. A System of Christian Doctrine, trans. Alfred Cave. Edinburgh: T. \& T. CTark, 1880 .

Duncan, John (Rabbi). Colloquia Peripatetica, ed. William Knight. 6th ed. Edinourgh and London: 01 iphant, Anderson, and Ferrier, 1907.

DuRoy: 0. J. "St. Augustine," New Catholic Encyclopedia, Vo1. I. New York: McGraw-Hi1 Book Company, 967 .

Durrant, Michael. Theology and Intellidibility. London: Routledge \& Kegan Pä 1973.

Faber, George Stanley. The Apostolicity of Tyinitarianism; or, the Testimony of History, to the positive Antiquity, arido the Apostolical Irculcation, of the Docirine of the Trinity. London: J. G. and F. Rivington, 7332. 
Fisher, George P. History of Christian Doctrine. Edinburgh: T. \& T. Clark, 1916 .

Fortman, Edmund J. The Triune God. Philadelphia: Westminster Press, 1972 .

Franks, R. S. The Doctrine of the Trinity. London: Gerald Duckworth and Co., LTD., 1953.

Fulton, W. "Trinity," The Encyclopedia of Religion and Ethics, ed. James Hastings, VoT. XII. Edinburgh: T. \& T. Clark, 1921.

Garvey, M. P. Saint Augustine: Christian or Neo-Platonist? Milwakee: Marquette University Press, 1939.

Gilson, Etienne. Being and Some Philosophers. Toronto: Pontifical Institute of Medieval Studies, 1952.

- Christian Philosophy in the Middle Ages.

London: - Sheed and Ward, 1955.

- The Christian Philosophy of St. Augustine,

trans. L. E. M. Lynch. New York: Random House,

1960 .

The Spirit of Medieval Philosophy. New York:

Charies Scrituer's Sons, 1936.

Theology and Philosophy. New Haven: Yale University Press, 1941 .

Glanville, J. J. "Aristotelianism," New Catholic Encyclopedia, Vol. I. New York: McGräw-Hill Book Company, 1967 .

Gonzales, Justo L. A History of Christian Thought, Vol. I. New York: Abingdom Press, 1970.

Grawbowski, Stanislaus. The All-Present God: A Study in St. Augustire. St. Louis: B. Herder Book Co., 7954 .

Grene, M. A Portrait of Aristotie. Chicago: The University of Chicagofress, 964.

Grote, George. Aristotle, ed, Alexander Bäin \& $f_{2}$. Croom Robertson. London: john Murray, 1872.

Hagglund, Bengt. History of Theology, trans. G. J. Lund. st. Louis: Concordia Pibtishing house, 1968. 
Hagenbach, K. R. A History of Christian Doctrines, Vol. I. Edinburgh: T. \& T. Clark, 1883.

Ha11, F. J. Dogmatic Theology, Vol. on the Trinity. New York: Longmans, Green, and Co., 1918.

Harnack, Adolph. History of Dogma, Vols. II and IV. London: Williams and Norgate, 1894.

Hedley, George. The Holy Trinity. Philadelphia: Fortress Press, $19 \overline{67}$.

Heick, 0. W. A History of Christian Thought, 2 Vols. Philadelphia: Fortress Press, 1966.

Henry, Paul. Saint Augustine on Personality. New York:

The Macmillan Company, 1960.

Hodge, Charles. Systematic Theology, Vol. I. Grand Rapids: Wm. B. Eerdmans Publishing Company, 1965.

Hodgson, Leonard. The Doctrine of the Trinity, 7 th ed. Digswell Place: James Nisbet and Co., 1964.

Hoeksema, Herman. Reformed Dogmatics. Grand Rapids: Reformed Free Publishing Association, 1966.

Illingsworth, J. R. The Doctrine of the Trinity. London: MacMi l 1 an and Co., 1907 .

Jaeger, W. Aristotle, trans. Richard Robinson. Oxford: Clarendon Press, 1950.

Joyce, G. H. "Trinity," The Catholic Encyclopedia, Vol. XV. New York: The Encyclopedia Press, 1913.

Kelly. J. N. D. Early Christian Doctrines. 2nd ed. New York: Harper and Brothers, 1960.

Kerferd, G. G. "Aristotle," The Encyclopedia of Fhilosophy, Vol. I. New York: The Macmilian Company and the Free Press, 1967.

Kirn, 0. "Doctrine of the Trinity," The New Schaff-Herzog Encyclopedia of Religious Knowledge, ed. S. M. Jackson, Vo]. XII. Grand Rapids: Eaker Book Co., 1964 .

Kittel, Gerhäd, ed. Theologicai Dictionary of the New Testament, trans. and ed. Geoffrey 
Grand Rapids: Wm. B. Eerdmans Publishing Company, 1968.

Knudson, Albert $C$. The Doctrine of God. New York: The Abingdon Press, T⿳亠口冋丁0.

Lebreton, Jules. History of the Dogma of the Trinity, Vol. I, trans. ATgur Thorold. 8th ed. London: Bums, Oastes, and Washbourne, LTD., 1939.

Leff, Gordon. Medieval Thought--St. Augustine to Ockham. Baltimore: Penguin Books, 1958 .

Lietzmanri, Hans. The Era of the Church Fathers, Vol. IV, trans. B. L. Woolf. London: Lutterworth Press, 1951 .

Lonergan, Bernardus. Divinarum Personarum. Romae: Apud Aedes Universitatis Gregorianae, 7959.

MCClintock, John, and Strong, James. "Trinity," Cyclopedia of Biblical, Theological, and Ecclesiastical Literature, Vol. $\bar{X}$. Grand Rapids: Baker Böck Co., 1970 .

McGiffert, A. C. A History of Christian Thought, Vol. II. New York: Charles Scribner's Sons, 1954 .

McInerny, R. M. "Categories of Being," New Catholic Encyclopedia, Vol. III. New York: McGraw-Hîll Book Co., 1967 .

Mallone, S. H. Leaders of Early Christian Thought. London: The Lindsey press, 1925.

Markus, R. A. "St. Augustine," The Encyclopedia of Philosophy, Vol. I. New York: The Macmillan Company and the Free Press, 1967.

Marrou, H. I. St. Augustine and His Influence through the Ages, trans. P. H. Scott. New York: Torchbooks, $195 \overline{8}$.

Martin, S. G.; et. al. A Histary of Philosoohy. New York: Appieton-Century-Crofts, Inc., 194.

Mattingly, B. "Relation," New Catholic Encyclopedia, Vol. XII. New York: McGraw-Hil1 Book Co., 1957.

Moravesik, J. M. E. "Aristotle's Theory of Categories," Aristotle, ed. U. M. E. Moravcsik. Notre Dame: University of Notre Dame Press, 1967. 
Mure, G. R. G. Aristotle. New York: Oxford University Press, 1964 .

Neander, Augustus. Generā History of the Christian Religion and Church, trans.Joseph Torrey. Boston: Crucker \& Brewster, $1865-18 / 0$.

Newman, John H. An Essay on the Development of Christian Doctrine, ed. C. F. Harrold. New York: Sheed and Ward, 7949.

O'Neill, R. F. "Quality," New Catholic Encyclopedia, Vol. XII. New York: McGraw-Hi11 Book Co., 1967.

Owens, J. "Aristotle," New Catholic Encyclogedia, Vol. I. New York: MCGraw-Hil1 Book Co., 1967.

Paine, Levi Leonard. Critical History of the Evolution of Trinitarianism. Boston: Houghton, Mifflin, and Company, 1900 .

Polman, A. D. R. The Word of God According to St. Augustine. Grand Rapids: Wm. B. Eerdmans Publishing Company, 1961 .

Portalie, E. "Augustine," The Catholic Encyclopedia, Vol. II. New York: Robert Appleton Co., 1907.

A Guide to the Thought of Saint Augustine, trans. Ralph J. Bastian. Chicago: Henry Regnery Co., 1960 .

Prestige, G. L. God in Patristic Thought. London: William Heinemann, Ltd., 1936.

Randa11, J.H., Jr. Aristotle. New York: Columbia University Press, 1960.

Rawlinson, A. E. J., ed. Essays on the Trinity and the Incarnation. London: Longmans, Green, and co., LTD., 1928 .

Richard, R. L. "Holy Trinity," New Catholic Encyclopedia, voi. XIV. New York: McGraw-HiT1 Book Co., T967.

Richardson, Cyril C. The Doctrine of the Trinity. New York: Abingdom ?ress, 1958.

"The Enigma of the Trinity," in A Companion to the study of St. Augustire, ed. Roy W. Battenhouse. New York: oxford University Press, 1969. 
Ross, W. D. Aristotle. London: Methuen \& Co., LTD., 7945.

Schaff, Philip. History of the Christian Church. Grand Rapids: Wm. B. Eerdmans Publishing Company, 1964.

- Saint Augustin, Melanchthon, Neander. New York: Funk \& Wagnalis, Publishers, 7386.

Shedd, William G. T. Dogmatic Theology, 2 Vols., 3d. ed. New York: Chartes Scribner's Sons, 1891 .

History of Christian Doctrine, Vol. IV. New York: Charles Scribner's Sons, 1891.

Siegfried, F. P. "Category," The Catholic Encyclopedia, Vol. III, New York: Robert Appleton Co., 1907.

Simpson, W. J. Sparrow. St. Augustine's Conversion. New York: The Macmillan Company, 1930. $1 \overline{944}$ St. Augustine's Episcopate. London: SPCK,

Sloyan, F. S. The Three Persons in One God. Englewood Cliffs, NJ: Foundation of Catholic Philosophy Series, 1964.

Smith, M. H. Systematic Theology, A Syllabus. Unpublished class notes, Reformed Theological Seminary; Jackson, Mississippi.

Strong, A. H. Systematic Theology, Vol. I. Philadelphia: The Griffith \& Rowland Press, 1907.

TeSelle, Eugene. Augustine the Theologian. New York: Herder and Herder, 1970.

Thompson, Maniey. "Category," Encyclopedia of Philosophy, Vol. II. New York: The Macmijian Company \& the Free Press, 1967.

Tilich, Paul. A History of Christian Thought, ed, C. E. Braten. New York: Harper and Row, 1968.

Tixerorit, Josaph. History of Dogmas, Vol. II. St. Louis: Herder Book Co., $19 \overline{2} 3$.

Tortey, Wirtiain $P$. The Idea of God in the Theology of St. Augustine. New York: Richará R. Smith, 1930 .

von Camperhausen, 4 . The Fathers of the Latin Church. London: A\& C B Tack, 1964 . 
103

Warfield, Benjamin B. "Augustine," Encyclopedia of Religion and Ethics, ed. James Hastings, Vol. II. Edinburgh: T. \& T. CT ark, 1909.

Calvin and Augustine. Philadelphia: The Presbyterian and Reformed Publishing Company, 1956.

York: Studies in Tertullian and Augustine. New York: Oxford University Press, 1930 .

"Trinity," International Standard Bible Encyclopedia, Vol. V. Grand Rapids: Wm. B. Eerdmans Publ fishing Company, 1939.

Werner, Martin. The Formation of Christian Dogma. New York: Harper and Brothers, 1957 .

Wiles, Maurice. The Christian Fathers. Philadelphia: J. B. Lippincott, $196 \overline{6}$.

Wolfson, Harry Austryn. The Philosophy of the Church Fathers, Bd. ed. Cambridge: Harvard University press, 1970. 